\title{
Frontlash: Race and the Development of Punitive Crime Policy
}

\section{Vesla M. Weaver, University of Virginia}

\author{
... fear in turn seeks repressiveness as a source of safety. [1970] \\ —Ramsey Clark, former Attorney General (1967-1969)
}

I sense there is a tendency to make crime in the streets synonymous with racial threats or the need to control the urban Negro problem. [1968]

-Dr. Kenneth B. Clark, sociologist whose doll studies were instrumental in showing that separate was not equal in Brown v. Board of Education

Civil rights cemented its place on the national agenda with the passage of the Civil Rights Act of 1964, fair housing legislation, federal enforcement of school integration, and the outlawing of discriminatory voting mechanisms in the Voting Rights Act of 1965. Less recognized but no less important, the Second Reconstruction also witnessed one of the most punitive interventions in United States history. The death penalty was reinstated, felon disenfranchisement statutes from the First Reconstruction were revived, and the chain gang returned. State and federal governments revised their criminal codes, effectively abolishing parole, imposing mandatory minimum sentences, and allowing juveniles to be incarcerated in adult prisons. Meanwhile, the Law Enforcement Assistance Act of 1965 gave the federal government an altogether new role in crime control; several subsequent policies, beginning with the Crime Control and Safe Streets Act of 1968 and culminating with the Federal Sentencing Guidelines, 'war on drugs,' and extension of capital crimes, significantly altered the approach. These and other developments had an exceptional and long-lasting effect, with imprisonment increasing six-fold between 1973 and the turn of the century. ${ }^{1}$ Certain groups felt the burden of these changes

1. See Figure 1 in this article, depicting the growth of the prison population and incarceration rate over time. most acutely. As of the last census, fully half of those imprisoned are black and one in three black men between ages 20 and 29 are currently under state supervision. Compared to its advanced industrial counterparts in western Europe, the United States imprisons at least five times more of its citizens per capita.

I argue that the punitive policy intervention was not merely an exercise in crime fighting; it both responded to and moved the agenda on racial equality. In particular, I present the concept of frontlashthe process by which formerly defeated groups may become dominant issue entrepreneurs in light of the development of a new issue campaign. In the case of criminal justice, several stinging defeats for opponents of civil rights galvanized a powerful elite countermovement. Aided by two prominent focusing events-crime and riots-issue entrepreneurs articulated a problem in a new, ostensibly unrelated domain-the problem of crime. The same actors who had fought vociferously against civil rights legislation, defeated, shifted the "locus of attack" by injecting crime onto the agenda. Fusing crime to anxiety about ghetto revolts, racial disorder-initially defined as a problem of minority disenfranchisement-was redefined as a crime problem, which helped shift debate from social reform to punishment. Thus, policies related to crime were part of a critical episode in race-making and protracted contest over the political agenda. 
What the literature usually treats as independent trajectories-liberalizing civil rights and more repressive social control in criminal justice-were part of the same political streams and the actors and incentives were components in an unfolding political drama that would alter significantly the federal government's role in crime policy and, more importantly, race in post-civil rights America.

First, I elaborate a framework for understanding how crime came to dominate the domestic agenda. Next, I go deep into the policy changes and the public and private debates that surrounded them. I describe how the pace and direction of federal action on crime changed, tracing the movement of crime policy through initial federal attention to crime, characterized by a focus on fairness in the system and root causes, and ultimately to the emergence of "law and order" policies. In the process, I highlight the possibilities that existed in the early period and the routes that were not followed. I analyze congressional hearings around important criminal justice policies, party platforms, campaign material and speeches, oral histories, key votes, commission reports, media and secondary accounts, presidential messages to Congress, media coverage, and government reports, complimenting these public sources with internal documents from Lyndon Johnson's administration. I focus mainly on the years from 1958 to 1974, paying closest attention to the years from 1965 to 1972, during which time attention to crime and policy change burgeoned.

\section{The Role of Politics in Crime Policy}

Two scholars of criminal justice recently observed: "Criminologists and sociologists rarely make the political dimension of crime policy a principal concern, and political scientists almost never do." ${ }^{2}$ I begin with the selective accounts that have begun to fill the vast lacuna of the political science of punishment. Marie Gottschalk's recent book centralizes the role of early developments and crusades against crime in leading to the building of the "carceral state"; she argues that each of these crime campaigns (and the social movements with which they interacted) left behind institutional residues which would enable later developments. ${ }^{3}$ While race is mentioned, its influence is underwhelming and often completely overlooked. In showing how social movements conditioned the latest crime campaign, the civil rights

2. Franklin E. Zimring and David T. Johnson, "Public Opinion and the Governance of Punishment in Democratic Political Systems," Annals of the American Academy of Political and Social Science 605 (2006): 267.

3. Marie Gottschalk, The Prison and the Gallows: The Politics of Mass Incarceration in America (Cambridge, UK: Cambridge University Press, 2006). movement is barely mentioned. While Gottschalk ably puts the lie to the notion that law and order campaigns were a recent phenomenon, this point comes at the cost of underestimating the genuine distinctiveness and importance of the crime policy changes that occurred starting in 1965, which ushered in a truly new scale of imprisonment. Unlike past episodes, the latest crime campaign launched the United States to the world record for incarcerating the largest proportion of its citizens.

David Garland's book also provides a long historical perspective. In this work, social, cultural, and economic developments of "late modernity" greatly weakened the penal-welfare state. ${ }^{4}$ A complex, all-encompassing set of macrohistorical and societal factors-including but not limited to women entering the labor force, modernization of capitalist production, demographic changes and suburbanization, changes in family structure and divorce, and technological advances in the media (particularly the rise of television)-together are responsible for both more crime and more incarceration. Through this oversimplification, the primary actor is society itself and every change that characterized the latter half of the twentieth century; in short, the theory is overdetermined and offers a very loose framework for how social disorganization created insecurity and general anxiety about disorder to the detriment of laying out more proximate mechanisms behind policy change and legislative activism on crime.

Jonathan Simon's recent book, Governing Through Crime, refines the generality of Garland's thesis and is not beset by Gottschalk's failure to recognize the true distinctiveness of the post-1960s crime mobilization. Simon argues that the United States has created a new political order and mode of governance that is structured around crime and the fear of crime; crime has become " $a$, if not the, defining problem of government." Governing through crime has become the dominant mode-whether in managing crime risk, valorizing the victim in political discourse, or in using crime as a legitimate reason for action in other domains. While Simon's focus is differentthe consequences of this reordering and transformation for democracy-his account compellingly highlights the political dimension of crime politics and the ways institutions and governance were transformed by the various "wars on crime." Using original historical counterfactuals, Simon convincingly demonstrates that crime was the path of least resistance for government intervention and innovation and the crime problem actually became a "solution" to the

4. David Garland, The Culture of Control: Crime and Social Order in Contemporary Society (Chicago: University of Chicago Press, 2001).

5. Jonathan Simon, Governing Through Crime: How the War on Crime Transformed American Democracy and Created a Culture of Fear (Oxford: Oxford University Press, 2007), 13. 
problem of governance left by the New Deal. Through his account, we see how crime legislation during the 1960s was not simply legislation but was critical in the forging of a new governing coalition and in presenting crime as a priority for government. In his words, "That legislation and the metaphoric mapping of American society it promoted remain, I would argue, the dominant interpretive grid on which governable America is known and acted upon by government officials at all levels." 6

Several scholars have advanced the idea that crime policy transcends the instrumental logic of reducing crime and is better understood as deeply symbolic. The overarching theme in these accounts is that crime is a symbol for other societal anxieties. ${ }^{7}$ Scheingold argues that crime policy is a "product of political decisions rather than moral or functional imperatives." ${ }^{8}$ In a similar vein, Morone and Meier argue that crime and drug policy exist in the category of "morality politics," or "policies that redistribute values rather than income." 9 Race is the axiomatic example. Racial motivations take a central place in the crime drama, particularly for Katherine Beckett, Bruce Western, and Naomi Murakawa. ${ }^{10}$ In addition to his economic account of the prison, sociologist Bruce Western argues that "the prison boom was a political project that arose partly because of rising crime but also in response to an upheaval in American race relations in the $1960 \mathrm{~s} . " 11$ Katherine Beckett presents a similar argument: "In short, the creation and construction of the crime issue in the $1950 \mathrm{~s}$ and 1960 s reflect its political utility to conservative opponents of social and racial reform." ${ }^{12}$ Beckett identifies a relationship between the initiative of elites and the media and changes in public opinion. Natalie Murakawa's research goes even further in theorizing about the connection between crime and race. She posits a "race-laden electoral connection" in which crime policy is developed in a context

6. Ibid., 8 .

7. Michael Tonry, Malign Neglect-Race, Crime, and Punishment in America (New York: Oxford University Press, 1995); Stuart Hall et al., Policing the Crisis: Mugging, the State, and Law and Order (London: Macmillan, 1978); Garland, Culture of Control; Stuart A. Scheingold, The Politics of Law and Order: Street Crime and Public Policy (New York: Longman, 1984).

8. Scheingold, Politics of Law and Order, 5.

9. Kenneth J. Meier, The Politics of Sin: Drugs, Alcohol, and Public Policy (Armonk, NY: M.E. Sharpe, 1994); James A. Morone, Hellfire Nation: The Politics of Sin in American History (New Haven, CT: Yale University Press, 2003), 455-77.

10. Katherine Beckett, Making Crime Pay: Law and Order in Contemporary American Politics (New York: Oxford University Press, 1997); Bruce Western, Bruce, Punishment and Inequality in American Democracy (New York: Russell Sage Foundation, 2006); Loic Wacquant, "The New 'Peculiar Institution': On the Prison as Surrogate Ghetto," Theoretical Criminology 4 (2000): 377-89; Naomi Murakawa, "Electing to Punish: Congress, Race, and the American Criminal Justice State" (PhD diss., Yale University, 2005).

11. Western, Punishment and Inequality, 5.

12. Beckett, Making Crime Pay, 28-29. where parties and legislators have incentives to proffer racial framings of the crime problem, and because the costs of the policies are "racially concentrated," there are few checks on the "punitive bidding wars" that result. Murakawa's account is a unique contribution of how racial power in the U.S. intersected with electoral incentives to create a durable punitive framework. Unlike other accounts, she presents an aggressive account of why crime policy is tied to race and in locating the importance of how crime was framed in the 1960s, providing a rich description of problem framings and party convergence.

While Murakawa, Beckett, and Western all consider the civil rights era an important moment in the development of punitive crime policy to different degrees and make bold claims about the racially inflected motivations of elites, why that is the case is not altogether clear and there is a mismatch between the scale of their claims and the research to support it, a mix of thick descriptive anecdotes and quantitative analyses that skip over the process of change. Their research contains a similar view of the manner in which crime was framed in congressional legislation during 1960s. Indeed there are symmetries between our accounts and the emphasis we place on critical factors-changing crime discourse, the importance of elites, and the emboldened federal role. The key difference is that while they assert a connection of civil rights agenda to crime, that connection is underspecified.

All pay attention to this historical moment and to how legislative incentives are molded by race, yet the question of "why the 1960s?" remains undertheorized. Why did race come to matter when it did? For instance, Murakawa hypothesizes that "mandatory minimum statutes will increase with the waning political power of civil rights agendas"; however, her quantitative analysis, while quite original, does not bring us near that conclusion, finding only that mandatory minimums are related to the electoral cycle. Simon asserts that civil rights was a very probable issue for "recasting New Deal governance" but that it was "stymied easily when the crime agenda decisively sprinted ahead," without considering the possibility that these two developments were not merely coincidental. $^{13}$

I contend that these accounts are important first steps in theorizing the role of race in crime policymaking, and their ambiguity is the motivation for a deeper investigation. These accounts highlight the political dimension of crime policy and the role of race, but they hesitate in fully articulating just how and why racial conflict came to matter in shaping criminal justice, at which part of the policy process it came to matter, and the particular mechanisms that are driving the outcomes; without an adequate

13. Simon, Governing Through Crime, 28. 
theory, they fall short of empirically testing their instincts. This article continues in their path by deepening the mechanisms in their accounts and bringing into historical conversation the path of criminal justice and civil rights. Rather than being seen as critical of these accounts though, I use them as stepping stones to further our understanding of the political development of crime policy. I pause longer at the historical moment they identify, and, in so doing, find a more complex and nuanced developmental process.

The idea that conservatives used race and crime in strategic ways is neither novel nor unique to the criminal justice literature; research on the civil rights era oft mentions law and order and Nixon's southern strategy. Although not specifically concerned with explaining criminal justice, several historical accounts and one important recent work acknowledge the linkages between social change in the 1960s and repressive responses. ${ }^{14}$ In his historical account of "law and order," Michael Flamm centers race and civil rights in the analysis: "For conservatives, black crime would become the means by which to mount a flank attack on the civil rights movement when it was too popular to assault directly." 15 Other scholars have shown how crime has become a racial codeword, strategically employed by vote-seeking politicians. ${ }^{16}$ The strong association of crime with blacks leads one scholar to note that, "later discourse about crime is discourse about race." ${ }^{17}$ However, within political science, racialized framings are treated as simply a rhetorical appeal without lasting policy implications. One must look to other policy domains, particularly welfare, for research on how race has affected the development and politics around policies. ${ }^{18}$

14. Michael W. Flamm, Law and Order: Street Crime, Civil Unrest, and the Crisis of Liberalism in the 1960s (New York: Columbia University Press, 2005); Thomas E. Cronin, Tania Z. Cronin, and Michael F. Milakovich, U.S. v. Crime in the Streets (Bloomington, IN: University of Indiana Press, 1981); Richard M. Scammon and Ben J. Wattenberg, The Real Majority (New York: Coward-McCann, Inc., 1970); Malcolm M. Feeley and Austin D. Sarat, The Policy Dilemma: Federal Crime Policy and the Law Enforcement Assistance Administration, 1968-1978 (Minneapolis: University of Minnesota Press, 1980).

15. Flamm, Law and Order, 22. Also see Steven E. Barkan, Protesters on Trial: Criminal Justice in the Southern Civil Rights and Vietnam Antiwar Movements (New Brunswick, NJ: Rutgers University Press, 1985); James W. Button, Black Violence: Political Impact of the 1960s Riots (Princeton, NJ: Princeton University Press, 1978); Cronin, Cronin, and Milakovich, U.S. v. Crime in the Streets.

16. Tali Mendelberg, The Race Card: Campaign Strategy, Implicit Messages, and the Norm of Equality (Princeton, NJ: Princeton University Press, 2001).

17. Melissa Hickman Barlow, "Race and the Problem of Crime in Time and Newsweek Cover Stories, 1946-1995," Social Justice 25 (1998): 178; emphasis in original.

18. Martin Gilens, Why Americans Hate Welfare: Race, Media, and the Politics of Antipoverty Policy (Chicago: University of Chicago Press, 1999); Robert C. Lieberman, Shifting the Color Line: Race and the American Welfare State (Cambridge, MA: Harvard University Press, 1998); Jill S. Quadagno, The Color of Welfare: How Racism Undermined the War on Poverty (New York: Oxford University Press, 1994); Ira Katznelson, When Affirmative Action was White: An Untold History of
The remainder of the article investigates the process of problem definition and the considerations that went into policy change. But the most obvious explanation for why crime came to the center of the agenda is that crime got much worse. The accounts discussed earlier share a common feature: they dismiss crime outright as a potential explanation, but the grounds on which they refute crime are shaky. Most base their claims on the axiom of criminological research-that there is virtually no empirical correlation between crime trajectories and incarceration or between the incidence of crime and public concern with crime. ${ }^{19}$ While I agree with this thesis, I propose a different explanation for what motivated policy changes. Proponents of the crime-is-not-cause congregation raise a panoply of illustrative evidence. Incarceration steadily increased during the 1970s, 1980s, and 1990 s, as the argument goes, regardless of whether crime was rising or falling. Crime was rising long before incarceration started to increase. Moreover, according to this argument, variation in crime among the states does not explain variation in state imprisonment. In showing the crime rate to be largely orthogonal, extant studies have focused on the crime-incarceration and public opinioncrime linkage, not crime-policy change. However, studies where incarceration is not the dependent variable have found an effect of crime; for example, the national budget and congressional activity are responsive to changes in crime. ${ }^{20}$ Other accounts not only challenge the influence of crime, but reject the rise in crime in the 1960s altogether. Evidence for this bold claim is questionable, usually resting on the fact that crime increased steadily after WWII so that the increase during the 1960 s continued an upward pattern that was not distinct from the $1950 \mathrm{~s}^{21}$

While it is true that criminal justice legislation has not responded mechanically with fluctuations in crime rates, in their eagerness to dismiss crime, they have thrown the baby out with the bathwater. The

Racial Inequality in Twentieth-Century America (New York: W.W. Norton \& Company, 2005); Ange-Marie Hancock, The Politics of Disgust: the Public Identity of the Welfare Queen (New York: New York University Press, 2004).

19. Sean Nicholson-Crotty and Kenneth J. Meier, "Crime and Punishment: The Politics of Federal Criminal Justice Sanctions," Political Research Quarterly 56 (2003): 119-26.

20. Greg A. Caldeira and Andrew T. Cowart, "Budgets, Institutions, and Change: Criminal Justice Policy in America," American Journal of Political Science 24 (1980): 413-38; Willard M. Oliver, "The Power to Persuade: Presidential Influence Over Congress on Crime Control Policy," Criminal Justice Review 28 (2003): 113-32; Willard M. Oliver and David E. Barlow, "Following the Leader? Presidential Influence Over Congress in the Passage of Federal Crime Control Policy," Criminal Justice Policy Review 16 (2005): 267-86.

21. Malcolm M. Feeley, "Crime, social order and the rise of neo-Conservative politics,” Theoretical Criminology 7 (2003): 111-30. 


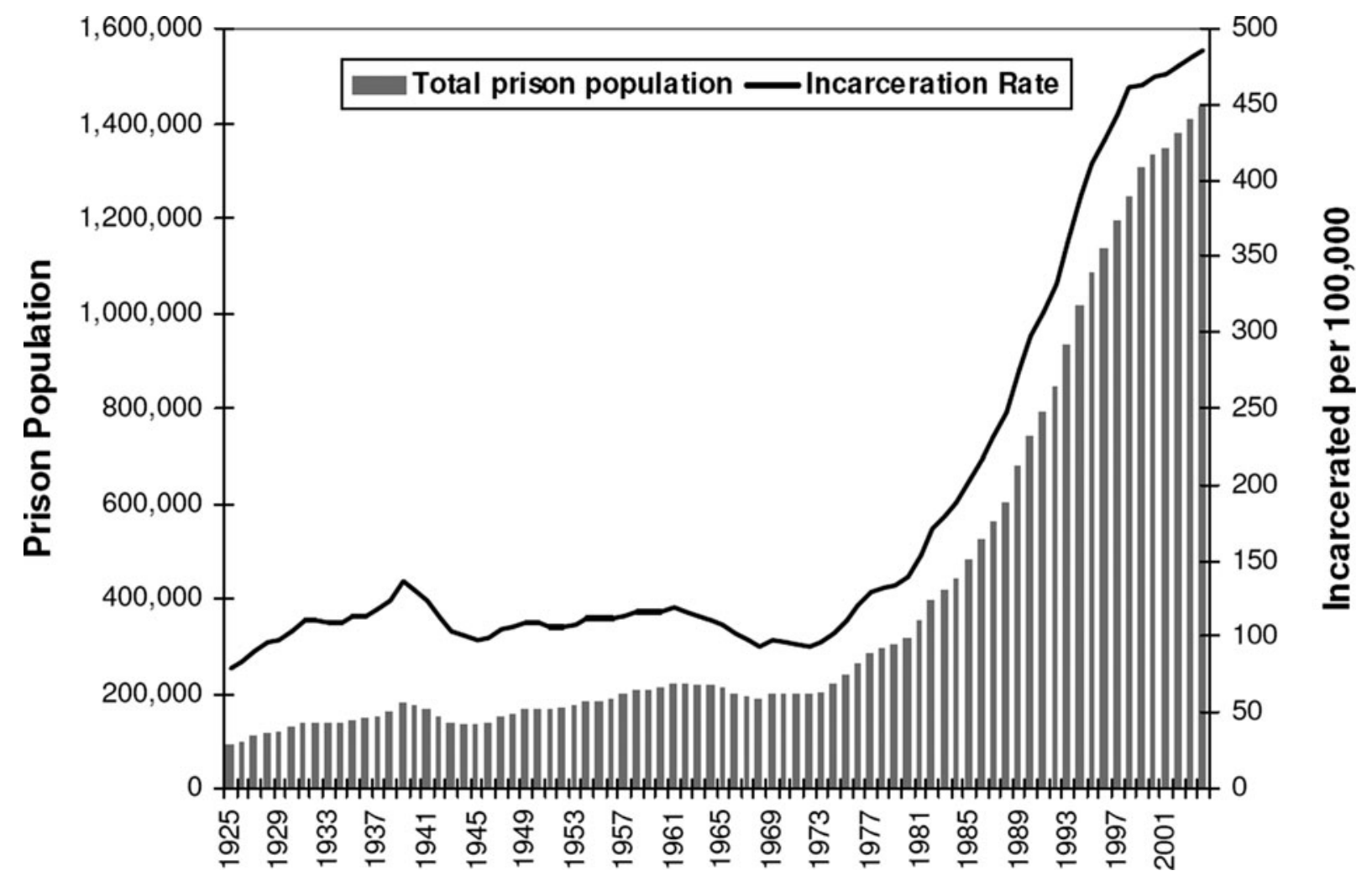

Fig. 1. Imprisonment in the United States, 1925-2002.

Source: Sourcebook of Criminal Justice Statistics Online (www.albany.edu/sourcebook/pdf/t6282004.pdf), Table 6.28.2004: "Number and rate (per 100,000 resident population in each group) of sentenced prisoners under jurisdiction of State and Federal correctional authorities on December 31. By sex, United States, 1925-2004."

Note: Data does not include local jail population.

above points are useful but not to conclude that crime is wholly inconsequential; a more fruitful discussion is to understand why crime came to be politicized in the 1960s and not before and unearth the full quilt of motivations embodied in its being elevated to a the status of major national problem. In other words, in refusing to attribute any role to crime, these studies are forced into the same zero-sum framework they attempt to challenge. As Figure 2 demonstrates, crime rose steeply in the 1960 s, particularly propertybased offenses. Indeed, as I discuss later, crime statistics were by far not the objective measure of actual crime and were often tweaked. So it is possible that the crime figures were untrustworthy. Setting aside the accuracy problems in gauging crime, crime can matter in a host of other ways and the perception of a crime wave can be even more important than reality. Media can facilitate a fictitious crime rise through biased coverage or highly visible crimes, politicians can signal the importance of the problem by alluding to crime in their campaigns, and the resolution or ascendance of other issues can give disproportionate influence to the issue of crime.
I agree that crime is not the primary explanation; however, I part company with the accounts that argue that its tenuous relationship to punishment is simply because it has no link to incarceration or that the crime problem was overestimated. Crime did rise quite substantially and the homicide rate, by far the most unbiased measure of violent crime, saw a precipitous rise. Demographic changes and technical innovations in crime reporting ensured that even without society becoming more violent, crime would have still been a serious problem. Mine is a different argument-that crime is a partial explanation that cannot fully explain the ways in which the problem was addressed. I do not dismiss crime. Much like the actual presence of Communist affiliates in the anticommunist frontlash against unions and New Deal policies-a case I discuss below-crime was a rising problem in the United States; however, it also operated as a symbol for other motivations. The question is not just whether crime was a rising problem, but what factors best explain the way it was defined and why understandings and approaches changed and subsequently, why the policies to deal with crime departed course. Crime might have been 


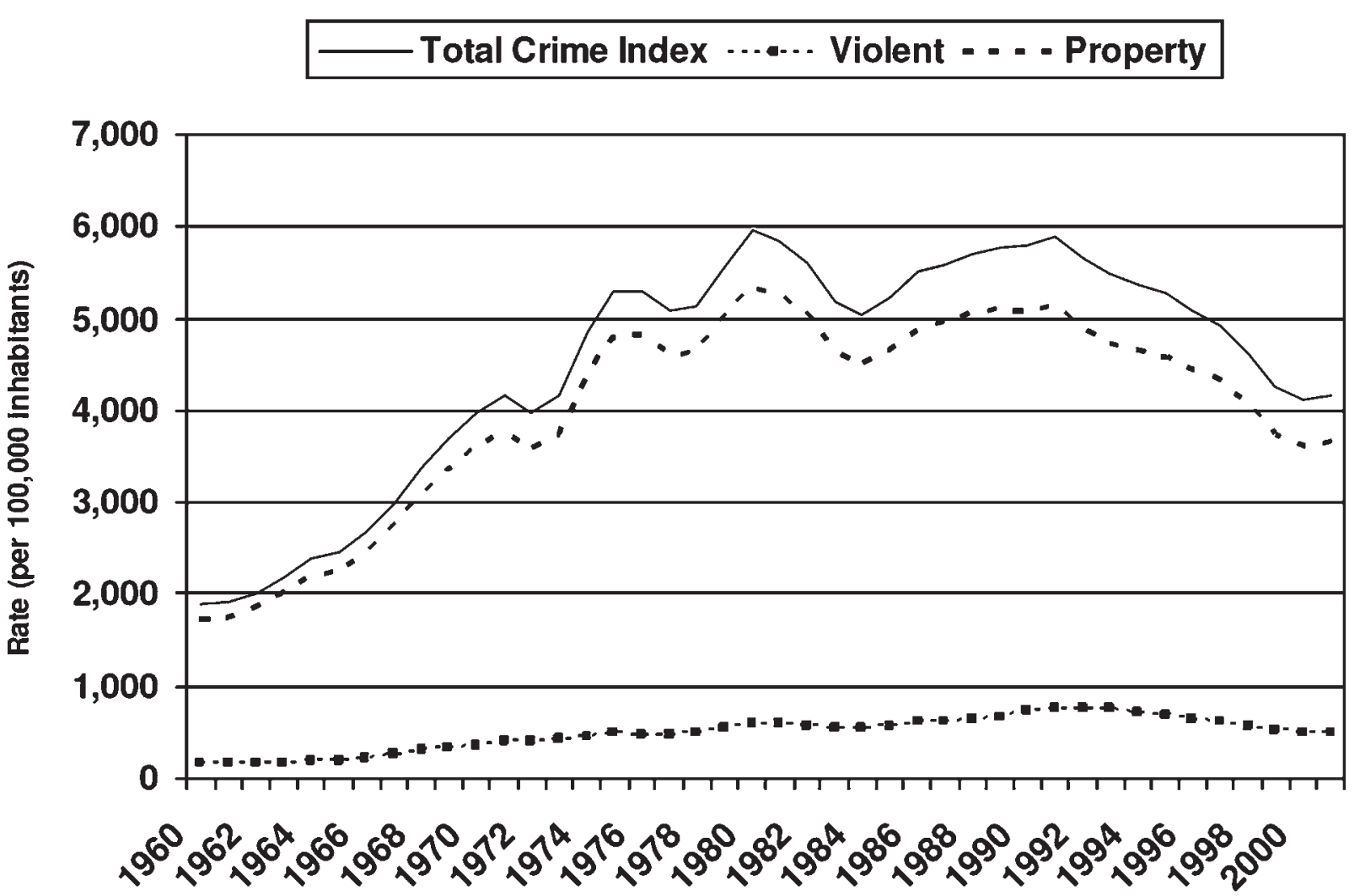

Fig. 2. The Crime Rate Overtime by Offense Type, 1960-2001.

Source: Sourcebook of Criminal Justice Statistics Online (www.albany.edu/sourcebook/1995/wk1/t3103.wk1), Table 3.103: "Estimated number and rate (per 100,000 inhabitants) of offenses known to police, by offense, United States, 1960-2001." Based on the Uniform Crime Reports.

rising, but the primary catalyst was to be found elsewhere. Without elite goals and shift in power, crime and violence were merely objective conditions. Deep investigation into how the issue was framed and negotiated in the political process provides crucial insights into when and under what conditions crime came to be an urgent social problem.

Several factors cast a doubtful shadow on the intrinsic value and singular role of crime in shaping the agenda. First, crime was rising for almost a decade before it was defined as a problem in the machinery of politics, which serves as an important reminder of Blumer's point that social problems are attached to processes of collective definition. ${ }^{22}$ Second, crime can be addressed in a variety of ways-from more prevention to more punishment. The simplistic assumption that increases in crime are behind changes that led to increasing prison populations ignores the politicization of the issue, how target groups were socially constructed, and elite incentives and agency. A crime boom might explain heightened attention to the issue but only goes part of the way in

22. Herbert Blumer, "Social Problems as Collective Behavior," Social Problems 18 (1971): 298-306. explaining the punitive path and expansion in federal authority. Crime is not divorced from other factors that affect its politicization; only a naïve observer would conclude that other crime campaigns were solely about crime. Would one be comfortable assuming, to draw on a few examples, that Prohibition was only about a rise in alcohol-induced violence, that concern over immigrant crime in the 1920s had nothing to do with anti-immigrant sentiment, or that the scare over cocaine-addicted blacks during the 1920 s (or the modern war on drugs) was singularly motivated? Conversely, the historical record is replete with cases when crime rose but was not followed by punitive legislation or a national campaign, including rising crime in the post WWII period.

So while crime does figure in the story, it is not the main character. Crime did rise and it does matter, but two additional factors suggest that it was not the sole motivation: (1) criminals began to receive longer sentences for the same crimes in the United States (2) the risk of incarceration increased steeply. ${ }^{23}$ Therefore, somewhere in the process of policy adoption,

23. Western, Punishment and Inequality. 
legislators decided to punish the same offenses more. I will devote much of the following to exploring the motivations for policy. Mine is an argument not about whether crime rose, but on how it came to be defined and politicized.

To cover the expanse of literature on why punitiveness has become gospel, it would take an encyclopedic treatment, which is not my purpose. This article seeks not to prove existing accounts wrong, but rather to expand them both in theoretical and empirical depth. To do that requires the articulation of a theory that does not isolate crime policy from the political agenda or from other policy domains. In so doing, it becomes clear that existing accounts are not so much wrong as seriously incomplete.

\section{Toward a New Theory}

To explain this developmental process in criminal justice, I advance the notion of frontlash, or the process by which losers in a conflict become the architects of a new program, manipulating the issue space and altering the dimension of the conflict in an effort to regain their command of the agenda. Frontlash hinges on the presence of winners and losers of a recent political conflict. In the aftermath, new norms are born and institutionalized, which "involves a shrinkage and rejection of positions that previously had been deemed acceptable." 24 But despite the score being settled on one conflict, losers do not disappear once defeated, nor do their ideologies. Rather, the losers seek to "preserve but also perpetuate the distribution of power emanating from those salient [past] political conflicts," rendering the results of the past conflict fundamentally unstable. ${ }^{25}$ The dissatisfied parties seek openings to mobilize a new issue, alter the dimension of the conflict, or, in the terminology of social movement theorists, "shift the locus of attack." ${ }^{26}$ Rather than defend the status

24. R. Kent Weaver, Ending Welfare as We Know It (Washington, DC: Brookings Institution Press, 2000), 37.

25. Edward G. Carmines and James A. Stimson, Issue Evolution: Race and the Transformation of American Politics (Princeton, NJ: Princeton University Press, 1989), 6. See also Frank R. Baumgartner and Bryan D. Jones, Agendas and Instability in American Politics (Chicago: University of Chicago Press, 1993), 6: "So long as the possibility exists of mobilizing the previously indifferent through the redefinition of issues, no system based on the shared preferences of the interested is safe." And William H. Riker, Agenda Formation (Ann Arbor: University of Michigan Press, 1993): "The political forces are the interests of politicians: previous winners, of course, seek to maintain the status quo of issues on which they have won, while previous losers seek to bring up new issues on which they can win."

26. E. E. Schaattschneider, The Semisovereign People: a Realist's View of Democracy in America (New York: Holt, Rinehart and Winston, 1960). Mayer N. Zald and Bert Useem, "Movement and Countermovement Interaction: Moblization, Tactics, and State Involvement," in Social Movements in an Organizational Society, Collected Essays, ed. Mayer N. Zald and John D. McCarthy (New Brunswick, NJ: Transaction Publishers, 1987), 247-72. quo ante then, losers propose new programs of action. By maneuvering into a new issue space and carving a new niche to mobilize around, the disadvantaged/defeated group opens the possibility of reversing its fortunes without violating established norms. If the issue definition is successful, it can manipulate the agenda in a way favorable to the interests of the losers and displace the prominent position of the old agenda issue. In addition to elite incentives catalyzed by defeat, an exogenous shock or dramatically altered environment can assist the mounting of a new issue campaign. Crises can provide opportunities to frame the introduction of a new problem, allowing the defeated group to "propose[s] a new interpretation of events" and "change the intensities of interest" in a problem. ${ }^{27}$ Finally, the losing actors from the previous struggle, though losing issue predominance, might remain in influential positions. Along with the articulation of a new issue problematic, entrepreneurs seek issue dominance by creating a monopoly on the understanding of an issue, associating it with images and symbols while discrediting competing understandings.

If the set of ideas is powerful enough and focusing events enlarge receptivity to it, the issue understanding can gain momentum and diffuse quickly, and frontlash will enter into its last stage-issue capture. Once one party in the conflict develops a monopoly on the understanding of an issue such that continuing opposition is a liability, "strategic pursuit" will usually ensue; in seeking to avoid blame, the disadvantaged side will position themselves nearer rivals despite this being outside their "zone of acceptable outcomes." 28 However, strategic pursuit can be a "perilous strategy" because it signals endorsement, narrowing the set of alternatives and discounting early conceptions; thus, it may further instantiate the issue understanding and proscribe policy options. ${ }^{29}$ Once the issue is captured, "secure policy subgovernments can and do build up around particular issues." 30

I show how frontlash occurred in crime policy, a critical episode in the development of criminal justice outcomes in the United States. The 1964 Civil Rights Act ended the "world's most developed system of racial servitude" and institutionalized strong norms of racial equality. ${ }^{31}$ As Crow had loosened its clutch, leaders of the old paradigm remained and sought to enlarge and shift the conflict strategically. They mobilized a new form of resistance,

27. Baumgartner and Jones, Agendas and Instability in American Politics, 8 .

28. Weaver, Ending Welfare as We Know It.

29. John B. Gilmour, Strategic Disagreement: Stalemate in American Politics (Pittsburgh, PA: University of Pittsburgh Press, 1995), 55.

30. Baumgartner and Jones, Agendas and Instability in American Politics, 34.

31. Katznelson, When Affirmative Action was White. 
shifting to a new policy domain by moving crime and criminal justice to the agenda. Two focusing eventscrime and riots-facilitated mobilization of the issue. The violent insurrections that swelled in the mid- to late-1960s created an opportunity to sharpen the connection of civil rights to crime. Strategic policymakers conflated these events, defining racial disorders as criminal, which necessitated crime control and depoliticized the grievance. Although tinged with racial subtext, this causal story did not disturb the newly institutionalized egalitarian precepts. Conservatives pitted toughness on crime against vigorous advocacy of civil rights by building a durable connection between black activism and crime. The liberal social uplift approach atrophied under the weight of this powerful doctrine. Sandwiched between two trapsbeing soft on crime and excusing riot-related violence-liberals had to forgo their ideal outcomes and moved closer to the conservative position. They engaged in strategic pursuit, emulating the conservative issue understanding, implicitly endorsing the linkages conservatives had drawn. This vindicated the conservative law-and-order doctrine and deepened the association between crime and racial discord, and ultimately, collapsed the liberal alternative for dealing with root causes. Once partisan consensus emerged, the elite countermovement was able to eclipse the dominance of the civil rights issue, assaulting it not from the segregationist platform but where it was weakest. Strategic entrepreneurs thus used the crime issue as a vehicle to advance a racial agenda without violating norms, attaching the outcomes of old conflict (Great Society programs and civil rights legislation) to the causes of the new problem-the breakdown of law and order.

\section{Revisiting the Backlash Narrative}

This endeavor is principally geared at understanding the transformation of criminal justice in the United States, but in embarking on that exploration, it became clear that it was part of a much grander dilemma in racial politics in the United States and demanded a revision of traditional stories of race in post-civil rights America. By this point, it is evident that the frontlash framework is a critique of another literature and concept that has become doctrine in accounts of race and American political development.

Backlash is the politically and electorally expressed public resentment that arises from perceived racial advance, intervention, or excess. The backlash term was first used with regularity by journalists, political observers, and academics prior to and in the wake of the 1964 presidential election. Initially, it described the 'Wallace phenomenon,' or the strong support George Wallace received in the Democratic primaries of several Midwestern states and Maryland and especially in the major cities of these states. ${ }^{32}$ It referred to working-class whites who shifted support to Wallace; thereafter, the label was applied to whites who deserted the Democratic Party to vote for Barry Goldwater. Later, scholars proffered what became termed as the backlash thesis (not to be confused with the earlier generic backlash label), which quickly became the orthodox view to explain the breakdown of the liberal New Deal consensus during the 1960s. ${ }^{33}$ According to this narrative, liberal excesses in the 1960 s caused the middle American voter to snap back, which led to the conservative hegemony. ${ }^{34}$ The steady decline of liberalism in the post-civil rights era is explained by whites who were antagonized by the Democratic Party's espousal of "special interests," especially minority groups. The "silent majority," as they came to be referred to, rejected the encroaching racial liberalism.

Despite the great common sense appeal and parsimony of the backlash account, it is more of a descriptive narrative and pseudo-theory for describing anti-black feeling expressed via election outcomes than a specified theory. In other words, there are no accounts that fully theorize the backlash concept, when and under what conditions it occurs, and the distinctions between its varioius formspolicy, electoral, political, and general backlash. It is not clear, for example, where backlash comes from, whether a policy intervention is required, and what threshold of reaction must be passed to be considered a backlash. Much like the ambiguity around its origins and motivation, it is equally unclear what the ultimate aim or target of backlash is-repeal of an advance, desert a party who has gone too far to the extreme, revert to some prior status quo condition, or simply to register anger. One might wonder how backlash is distinct from a moral panic, racial threat, or symbolic racism exploited by elite appeals. The analytic and theoretic components of backlash have not been elucidated; rather, backlash has been volleyed around as a term for describing any negative reaction to a whole host of racial threats, perceived and real. This lack of empirical propositions for what constitutes a backlash has enabled an unspecified range-from withdrawal of support to outright

32. Michael Rogin, "Wallace and the Middle Class: The White Backlash in Wisconsin," Public Opinion Quarterly 30 (1966): 98-108.

33. For an excellent review and critique of the backlash account, see Joseph Lowndes, The Southern Origins of Modern Conservatism (New Haven, CT: Yale University Press, Forthcoming 2008). He describes in more detail than I can here the history of the backlash narrative, how it soon became an ideological explanation for the conservative counterrevolution and is now the "ideological cornerstone" of the conservative strategy.

34. Thomas Byrne Edsall and Mary Edsall, Chain Reaction: The Impact of Race, Rights, and Taxes on American Politics (New York, Norton, 1992); Michael Kazin, The Populist Persuasion: An American History (Basic Books, 1995); Todd Gitlin, The Twilight of Common Dreams: Why America is Wracked by the Culture Wars (New York, Henry Holt \& Company, Inc 1995). 
violence-and an uncritical application of the term to a wide variety of groups and contexts-southerners, white ethnics, suburban whites, Midwestern Wallace voters, and working-class whites anxious over competition for jobs. It is therefore unclear which cases of racial conflict, if any, would not fall into this expansive and vague definition. In fact, we are not sure where backlash begins and ends and what the unique characteristics of backlash are.

This lack of clarity makes it a formidable task to distinguish concepts and raises doubts about the use of backlash as a conceptual tool. This can best be seen in the hasty way trends have been labeled backlash, when a case conveniently falls into the pattern of a negative reaction to any type of racial progress, combined with the inability to explain why other cases of racial advance do not fit the pattern. But the backlash account is flawed in another respect: the backlash thesis regards the transformation of politics as a fundamentally populist reaction. As a result, the backlash thesis overstates the degree to which a reactionary white electorate propelled developments verses elites. Based on a bottom-up view of growing disillusionment and inertia, this perspective gives total agency to undefined white masses, removing political initiative from elites and ignoring the incentives and opportunities that existed for an elite countermobilization and the new norms of racial equality they were bound by. ${ }^{35}$ It tacitly assumes that the developments that unfolded were driven by the mass public. Elites are often left out of the backlash story, and when they do appear, as in the Edsalls's account, elites are not formulating discourse or strategizing, they are onlookers with an eye toward anticipating public reaction, and acting accordingly. But why did the specter of racial change elicit such a reaction then and not other times - to the creation of minority majority districts for example? For the answer, we must turn to elites; in the latter example, it was not in the interest of conservative elites to argue against redistricting, because they benefited from it so there was little incentive to reframe the debate. In spite of these critiques, to fully understand frontlash it is useful to expound on the distinctions between frontlash and backlash and situate these concepts in regards to race.

We can think of backlash metaphorically as a bungee cord that snaps when stretched too far. In the more active account, seductive racial appeals catalyze the latent racial resentment of the white electorate. Backlash therefore entails a distinct tipping point; voters withdraw support or become

35. Joseph Lowndes's book on the conservative mobilization argues convincingly against the notion of backlash: "the Right that developed was contingent, mobile and highly adaptive, constantly responding to changing conditions on the ground with new strategies and tactics" (Lowndes, The Southern Origins of Modern Conservatism [New Haven, CT: Yale University Press, forthcoming 2008, chap. 7]). sympathetic to more extreme voices when pushed too far. Backlash is a mass mobilization of white hostility to an intervention or in support of a candidate, the epitomizing case being the white vote for George Wallace in Wisconsin in 1964, or hostility against such policies as affirmative action or racial busing. While backlash came to represent a post-1960s phenomenon, racial backlashes are not specific to the post 1960 s era. Based on an admittedly fuzzy definition, earlier examples might include backlash to the Brown decision that engendered the radicalization of southern whites and politicians, immigration reforms of the 1920s, or the 1863 New York draft riots. ${ }^{36}$

The key distinction then between frontlash and backlash consists in both the nature of the political reaction and the actors which carry that reaction to its conclusion. Backlash is reactive in a conservative dimension (aims to preserve the status quo and resist changes through emboldened opposition). Importantly, the main actors of consideration are the masses, the voting population which prompt elites to undertake certain policy positions with race in the foreground. Frontlash is preemptive, innovative, proactive, and, above all, strategic. Here, elites aim to control the agenda and resist changes through the development of a new issue and appropriation and redeployment of an accepted language of norms. The two conceptions also differ in terms of what might be a catalyst for their activation. For backlash, it is sometimes a policy, sometimes a candidate that stokes fears, sometimes broad civil rights developments that progress to uncomfortable levels for portions of the electorate. The catalyst in frontlash is defeat of longstanding political discourse or elite program.

Instead of a bungee cord recoiling when stretched too far, we can think of frontlash as water moving swiftly through a path that eventually comes to an end, forcing the water to seek alternative routes or as a weed that after being killed by weed killer mutates into a new variety, becoming resistant. It is strategic, alive, complex and sophisticated in its reaction. While racial/ethnic conflicts are good candidates because of the strong norms inherent to them, not all racial conflicts would necessarily result in frontlash. For example, the conflict over affirmative action did not result in a frontlash; rather it employed a prevailing norm-colorblind equality-to argue against "racial preferences" and "reverse discrimination." The fervent anticommunism spawned by union centralization in the $1930 \mathrm{~s}$ is a prominent example of frontlash. An increasingly activist government sympathetic to unions threatened the interests of business leaders and conservative legislators.

36. Michael J. Klarman, "How Brown Changed Race Relations: The Backlash Thesis," Journal of American History (1994): 81. 
This coalition strategically attacked a strong labor movement (and a supportive federal government) by connecting it to a "Red menace" and enlisting the fears of communist subversion, sidestepping issues of economic concern. Charging instead that workers' grievances were based on communist agitation, they argued for a crackdown on radicalism and labor unrest. These charges had some basis in reality; there were pockets of Communist Party affiliation in labor organizations including the CIO. Redefining the issue in terms of subversion rather than legitimate economic demands helped create an image favorable to business and shifted the dimensions of conflict. As the strategy developed, the American Legion, anti-labor business, and politicians on the Right claimed that Roosevelt's New Deal agencies had been infiltrated by Communists, discrediting the popular social programs. The House Un-American Activities Committee (HUAC) was created in 1938 to root out Communist Party influence. "HUAC's anticommunist investigations offered a more effective way to fight the New Deal than opposing its economic and social reforms." 37 Ultimately, this strategic issue redefinition and capture weakened the New Deal, liberalism, and labor unions.

By departing from backlash, I do not mean to impose a false dichotomy of terms, but rather, sharpen our view of elite incentives and thereby focus on a neglected history and important part of the conservative strategy. Rather than dismissing the backlash thesis writ large, frontlash revises and elongates the view of post-civil rights developments and brings into view developments that have been treated as merely coincidental. Without frontlash, we would mistakenly attribute the rise in incarceration to the much later war on drugs and fail to see how it developed out of the struggles of the 1960s. By sidestepping consideration of elite incentives, the backlash framework cannot explain the sudden mobilization of the crime issue and its connection to the rights revolution. It can explain why in the hundreds of articles and books on the Civil Rights Movement and its decline, there is comparatively little on its linkages with the issue that replaced it on the agenda and became a cornerstone of the conservative domestic program.

Frontlash adds another dimension to the backlash narrative because it can show how policies that usually are considered separately are actually part of same political history; developments in one domain can and do influence strategic decisions or new developments in another, ostensibly unrelated, sphere. In explaining the sustained shift in criminal justice then, my account unintentionally posits a different view of why the powerful civil rights agenda eroded.

37. Ellen Schrecker, The Age of McCarthyism, a Brief History with Documents (Boston, MA: St. Martin's Press, 1994).

\section{The Political History of Crime Policy: From Great Society to War on Crime}

Prior to 1960 , federal involvement in crime and law enforcement was limited. ${ }^{38}$ Presidents rarely touched on crime in their public addresses or private messages; party platforms were silent on the issue. The federal government was proscribed from interfering in what was believed to be a state and local concern, only having jurisdiction in cases of treason and espionage, mail fraud, and counterfeit crime. The Department of Justice (DOJ) was a small entity which only prosecuted Internal Revenue Service (IRS) cases with an emaciated budget. Federal Bureau of Investigation (FBI) Director J. Edgar Hoover was the sole voice in this vacuum, fervently speaking about the mounting rate of serious crimes and predicting a further increase. He lamented the public's "submissive attitude," saying "law enforcement has not yet attained the measure of public support it justly deserves." 39 He was partially right; the FBI reports showed that crime was increasing-it increased 66 percent in the 1950s-but there was little concern at the federal level. Rising crime rates in the $1950 \mathrm{~s}$, as far as we can take them as fact, were not initially followed by punitive legislation or a coordinated federal attack on crime. ${ }^{40}$ To the contrary, the only anticrime legislation that was passed in this decade concerned specific incidents-gambling and racketeering, crime in planes, obscene mail, and drunk driving. ${ }^{41}$

This is not to suggest the federal government had never been involved in crime control. As Gottschalk documents, there were several other highly visible crime campaigns that resulted in "bursts" of federal attention: kidnapping, attention to immigrant crime in the 1920s, prohibition, Kefauver's highly publicized organized crime hearings all over the country, juvenile delinquency in the $1950 \mathrm{~s}$, airplane

38. For a history of anti-crime legislation prior to 1960 see James D. Calder, The Origins and Development of Federal Crime Control Policy: Herbert Hoover's Initiatives (Westport, CT: Praeger, 1993). This discussion should not be taken to suggest the federal government had never been involved in crime control. Indeed, many national leaders and presidents employed the crime issue before Goldwater and Nixon, including Teddy Roosevelt, Joseph McCarthy, and Estes Kefauver. However, none of these campaigns resulted in a sustained national program on crime.

39. J. Edgar Hoover, “An American's Challenge: Communism and Crime" [address 9 Oct. 1962], Vital Speeches of the Day 29 (1962): 99; J. Edgar Hoover, "Our Common Task: When Crime Occurs, There has been a Failure Somewhere" [address 3 Oct. 1955], Vital Speeches of the Day 22 (1955): 43.

40. There are technical reasons to be dubious about the accuracy of crime rates. Until the 1970 s, the sole source of crime was the FBI's Uniform Crime Reports. The Bureau today strongly discourages academics and others from using its statistics prior to 1960 because police departments varied widely in their professionalism and participation in the UCR was sporadic.

41. The lone exception to this was a bill that attempted to challenge the Supreme Court's ruling on confessions, the Mallory rule. The bill passed in the House but was not acted on by the Senate. 
hijackings, and the heightened attention to crime and prostitution during the Progressive Era. ${ }^{42}$ Hoover's Wickersham Commission (formally the National Commission on Law Observance and Enforcement) proposed a national effort to conduct research and improve law enforcement and overhaul criminal procedure. Indeed, many national leaders and presidents employed the crime issue before Goldwater and Nixon, including Teddy Roosevelt, Joseph McCarthy, and Estes Kefauver. However, none of these campaigns resulted in a sustained national program on crime. Gottschalk even notes that "in earlier periods, the state's skeletal criminal justice institutions kept a check on these moral crusades" and that "most of the penal reforms of this era were enacted and implemented by local or state authorities" even if they garnered national attention. ${ }^{43}$ As will become clear below, the 1960s crime campaign is set apart from the others in scope and impact. Figure 3 illustrates dramatic rise in legislative activity and federal financial commitment to crime and criminal justice over time. The scale of federal involvement was of a new magnitude and changes broke entirely new ground, establishing new precedents for federal action. The federal government had waged crime wars before, but never in ways that changed its role or shifted authority away from the state's constitutional powers to police.

The beginning of the next decade continued in the same direction. Hoover called for the adoption of "stiffer laws and a more stern policy" but got instead legislation that expanded the rights of defendants and increased fairness in the system. ${ }^{44}$ Several Supreme Court rulings-Mallory (1957), Mapp (1961), Gideon (1963), Escobedo (1964), and later, Miranda (1966)—had focused attention on the rights of criminal defendants and significantly curtailed the admissibility of evidence and confessions. While these Court decisions were sharply criticized for "handcuffing the police," bipartisan coalitions supported bail reform, indigent defense, and juvenile rehabilitation. These early priorities of the rights of the accused passed with minimal fanfare or controversy. Indeed, conservative congressional leaders such as Representative Roman Hruska (R-NE) and Senators James Eastland (D-MS), and Sam J. Ervin Jr. (D-NG) signed onto Attorney General Kennedy's Criminal Justice Act in 1964, which established the Office of Criminal Justice to oversee fairness in law enforcement and provided for a public defender system. However, this legislation did not make a significant change to criminal justice and its budget was fairly small. Attorney General Robert Kennedy created a Committee on Poverty and the

42. Calder, Origins and Development of Federal Crime Control Policy; Morone, Hellfire Nation.

43. Prison and the Gallows, 43-44

44. Hoover, "An American's Challenge," 99.
Administration of Justice; its report found that poverty had a greater impact on crime than was commonly assumed and proposed solutions for improving the handling of poor defendants in court. Several preventative programs aimed at youth crime were begun as well as treatment programs, prisoner reentry, and the creation of Halfway Houses. ${ }^{45}$ Therefore, to the extent that crime was on the national agenda, it was geared toward fairness, rights of the accused, and organized and juvenile crime.

In its first two years, the Johnson administration was similarly indisposed to making crime a federal issue, characterized by a mixture of neglect, fairness, and root causes, with almost equal emphasis on each. ${ }^{46}$ The administration purposefully avoided making crime a federal problem, a responsibility that would put the government in the vulnerable position of making promises it could not keep and priming public demand for swift results. Johnson viewed crime as a problem of urban blight, poverty, and racial discrimination and as a result, placed a strong emphasis on understanding underlying causes. He argued that through a war on poverty, crime would be reduced, and was hesitant to establish a crime program for the national government. In 1964, Johnson aide Jack Valenti wrote a memorandum: "Very frankly, I disagree with ... the formation of a Presidential Committee to study violence." 47 This passivity characterized the initial disposition of the Johnson administration.

In a striking break with this approach, the very next year, Johnson announced a "War on Crime." To understand why, we must consider the emergence of the arguments of the crime entrepreneurs in civil rights debates.

\section{Early Arguments against Civil Rights}

Three strategies connected crime to racial change. The first variation used by early opponents of civil rights legislation was the argument that the civil rights demonstrations were criminal acts. Southern congressmen had been trying for years to apply criminal charges to civil rights leaders and their followers. A coalition of southern senators (from Mississippi, South Carolina, Virginia, Alabama, Arkansas, and Florida) introduced legislation in 1961 to criminalize freedom rides and sit-ins. They argued that freedom-

45. These include most notably President Kennedy's Committee on Juvenile Delinquency, which spurred preventative programs like Mobilization for Youth and Harlem Youth Opportunities, Unlimited.

46. The folders on crime in the LBJ records reveal an erratic mix of issues, most of which occupied the spotlight only for a short period and were unconnected to a broader vision. Most often, the correspondence regarding crime is about blacks needing redress from violent resistance.

47. Memorandum for Dr. Eric Goldman from Jack Valenti, 3 Jun. 1964, LBJ Library, JL Judicial-Legal Matters 11/22/63-5/5/65. 


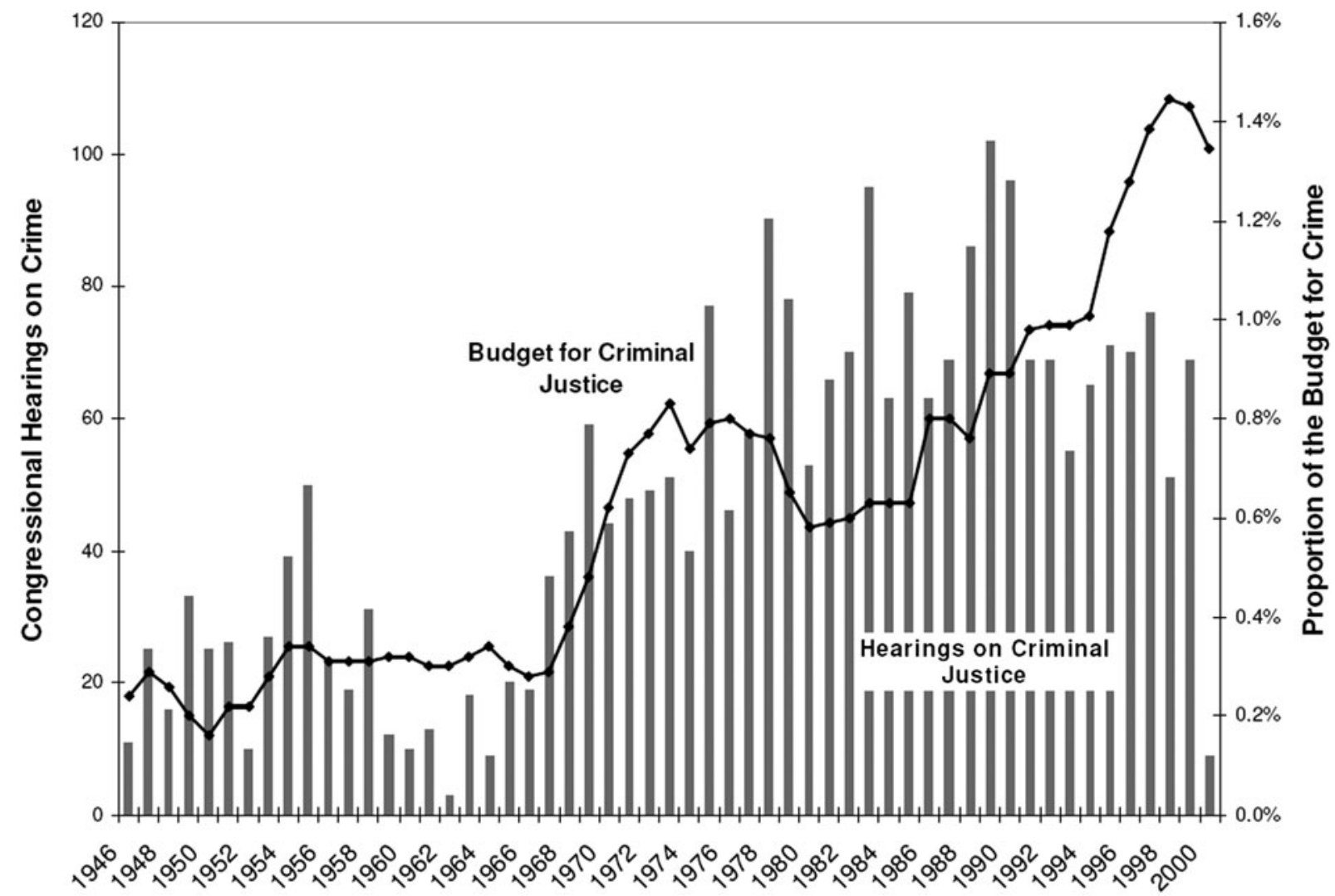

Fig. 3. Legislative Activity and Budget for Criminal Justice.

Source: Based on data from Baumgartner and Jones Policy Agendas Project. Frank R. Baumgartner and Bryan D. Jones, "Policy Agendas Project," National Science Foundation (NSF) grant number SBR 9320922; distributed through the Center for American Politics and Public Policy at the University of Washington and/or the Department of Political Science at Penn State University. Neither NSF nor the original collectors of the data bear any responsibility for the analysis reported here. See www.policyagendas.org (last accessed 14 Dec. 2005).

riders were using interstate commerce to incite riots and should be criminally punished:

As to the so-called freedom riders, it is well known that this trip originated far from the South, and had as its announced purpose a trip through several States where local statutes would be violated .... Instead of being encouraged by groups, and cast into the political arena, to be made a political issue, they should be made a violation of the criminal statutes. ${ }^{48}$

And in some places it was. State legislatures in Mississippi, Tennessee, Virginia, Georgia, and South Carolina implemented statutes with the aim of criminalizing NAACP actions. ${ }^{49}$ Immediately after the lunch counter

48. Sen. John C. Stennis (D-MS) in Proscription of Travel in Interstate and Foreign Commerce for Purposes of Inciting to Riot, $87^{\text {th }}$ Cong., $1^{\text {st }}$ sess., Congressional Record 107, pt. 2, 24 May 1961, 8738.

49. These statutes related to barratry, camperty, and maintenance, which meant arbitrary meddling in or stirring up legal suits. See Walter F. Murphy, "The South Counterattacks: The AntiNAACP Laws," in The Era of Integration and Civil Rights, 1930 1990, ed. Paul Finkelman (New York: Garland Publishing, Inc., 1992). sit-ins in 1960, states began passing laws with penalties specific to sit-ins and boycotters were brought in on laws that made it illegal to interfere with business.

The second variant to this crime/civil rights linkage was to argue that civil rights and integration would portend a crime wave by bringing violence-prone blacks to white neighborhoods. ${ }^{50}$ Senator Richard Russell's statement in 1960 is representative:

And, Mr. President, I say that the extremely high incidence of crimes of violence among members of the Negro race is one of the major reasons why the great majority of the white people of the South are irrevocably opposed to efforts to bring about enforced association of the races. ${ }^{51}$

Conservative congressmen also blamed "civil rights havens" for the increase in crime; Representative John Bell Williams (D-MS) argued:

50. Flamm, Law and Order, Murakawa, "Electing to Punish."

51. Sen. Richard B. Russell qtd. in Leasing of a Portion of Fort Crowder, MO-Civil Rights, $86^{\text {th }}$ Cong., $2^{\text {nd }}$ sess., Congressional Record 106, pt. 5, 16 Mar. 1960, 5721. 
This exodus of Negroes from the South, and their influx into the great metropolitan centers of other areas of the Nation, has been accompanied by a wave of crime.... What has civil rights accomplished for these areas? ... Segregation is the only answer as most Americans-not the politicians-have realized for hundreds of years. ${ }^{52}$

In the congressional debates over 1964 Civil Rights Act, opponents frequently referred to the fact that crime rates of Southern blacks were much lower compared to their Northern counterparts. ${ }^{53}$ In attempting to break a filibuster of the bill, Senator Jacob Javits $(\mathrm{R}-\mathrm{NY})$ contested the strategy to link crime and civil rights: "Another favorite diversion of the bill's opponents consists of alluding to crime rates in major northern cities." 54

Finally, as the first major legislative civil rights victories were under way, this argument was refashioned from prediction to explanation to challenge the passage of the Civil Rights Act of 1964. In the summer of 1964, the Harlem and Rochester race riots gave fuel to the familiar argument that had been percolating in the background of civil rights debates since the 1957 Civil Rights Act-that civil rights would engender a crime wave and integration would bring lawlessness. In this version of the argument, several Congressmen campaigned against passage of the Civil Rights Act of 1964 using the riots as testament to the fact that civil rights bred lawlessness. They argued that because the racial unrest happened in northern states with the most progressive social policy and civil rights, then poverty and racial discrimination could not be to blame. Instead, cities like Philadelphia and Rochester were described as being "victims of their own generosity"; by opening their arms to southern blacks, they were repaid with crime-ridden slums and black discontent. According to one of the major sponsors of later crime legislation, Senator John McClellan (D-AR), "The Civil Rights law is calculated to provoke, and is provoking, an attitude that is contrary to the concept of bringing

52. Rep. John Bell Williams in Northern Congressmen Want Civil Rights but their Constituents Do Not Want Negroes, $86^{\text {th }}$ Cong., $2^{\text {nd }}$ sess., Congressional Record 106, pt. 4, 9 Mar. 1960, 5062-63.

53. Linking blacks to crime was not unique to the civil rights era. It was a prominent theme in the First Reconstruction. Theodore Roosevelt was infamous for his exhortations that black criminals were "the worst enemy of his race": "Laziness and shiftlessness, these, and above all, vice and criminality of every kind, are evils more potent for harm to the black race than all acts of oppression of white men put together." See Theodore Roosevelt, Theodore Roosevelt on Race, Riots, Reds, Crime, comp. Archibald B. Roosevelt. (West Sayville, NY: Probe Publishers, 1968).

See also: David M. Oshinsky, Worse than Slavery: Parchman Farm and the Ordeal of Jim Crow Justice (New York: Free Press, 1996); Christopher R. Adamson, "Punishment after Slavery: Southern State Penal Systems, 1865-1890," Social Problems 30 (1983): 555-69.

54. Two Myths Behind Civil Rights Bill Opposition, $88^{\text {th }}$ Cong., $2^{\text {nd }}$ sess., Congressional Record 110, pt. 8, 5 May 1964, 10057. about an understanding and harmony between the races." 55

After the 83-day long filibuster led by southern Democrats, the civil rights bill was passed. This passage signified a major turning point in the civil rights conflict. Rather than a mere legislative setback, it marked a successful challenge of the segregationist platform and the establishment of the legal norm of racial equality. But racial contests were far from settled. It was a stinging defeat for conservatives, who now had a lingering incentive to make an end-run around civil rights. Rather than fading, the segregationists' crime-race argument was reframed, with a slightly different veneer, and became the fulcrum of the conservative's proposed agenda on crime. Although initially ineffective, this argument would provide the backbone of the successful campaign for tougher crime policy.

The following case illustrates how a losing group capitalizes on their interest in regaining dominance by enlarging the conflict. First, I show how arguments against civil rights were leaked into crime policy debates. In this, we will see how entrepreneurs leverage focusing events in order to define a problem, associate it with favorable images, and ultimately, secure a monopoly on the policy understanding.

\section{Expanding the Conflict: "Goldwater's Nightmares"}

Before 1960, crime was about the drunk, the "mad-dog sex killer," and the juvenile hoodlum. FBI Director Hoover tried to bring crime to the policy agenda and to public concern, most often proclaiming the link between communism and crime, but before 1960 , he was practically alone. ${ }^{56}$ When crime was discussed, there was no explicit and very little implicit connection of crime to blacks.

Despite Hoover's early rumblings about crime rises, the person to succeed in raising the public's awareness of crime and its connection to a wide variety of other social malaise was Barry Goldwater. Goldwater warned voters in 1964:

[C]hoose the way of this present Administration and you have the way of mobs in the street, restrained only by the plea that they [referring to black militants and civil rights

55. Sen. John L. McClellan in "Crisis in Race Relations-How Will It Be Met? Interviews with Congressmen around the Nation," US News E World Report, 10 Aug. 1964, 23-40, 28.

56 . In his early speeches on the topic, he focused on salaries for police, on corruption, juvenile crime, and most heavily on the connection of crime to communism. His admonitions included an incoherent description of the causes, which ranged from "selfindulgence" and the "moral breakdown of young people" to communism (the "sinister partner" of crime), to court decisions that help law violators. 
demonstrators] wait until after election time to ignite violence once again. ${ }^{57}$

To dramatize this point, the Goldwater campaign designed a television advertisement called "Choice" which depicted the mayhem of the Harlem riots in 1964 , later pulled because it was so inflammatory. ${ }^{58}$ It was replaced with an advertisement that began with these words: "Graft! Swindle! Juvenile Delinquency! Crime! Riots!"59 The same Goldwater who had opposed Kennedy's proposed National Crime Commission, arguing that it would lead to a national police force, ${ }^{60}$ wanted crime to be a focus of his presidency:

Crime grows faster than population, while those who break the law are accorded more consideration than those who try to enforce the law.... Our wives, all women, feel unsafe on our streets .... Perhaps we are destined to see in this law-loving land people running for office not on their stainless records but on their prison records. ${ }^{61}$

Goldwater is credited in almost folklore like ways with the first intimations of "law and order." While Goldwater was perhaps the first to vocalize the crime issue in a major political campaign and this is dramatized in most accounts, there is evidence that crime had become an important topic to several southern Democrats prior to Goldwater's orations. In a book about organized crime (the one area federal legislators could get involved in), John McClellan devoted the remaining pages to a new topic on his mind-crime in the streets-singling out the District of Columbia for particular emphasis and calling for "heavier penalties for insidious crimes." ${ }^{62}$ Goldwater campaign Director of Field Operations (and eventual attorney general in the Nixon administration) Richard Kleindienst has been credited by some as the driving force behind the turn toward law and order. ${ }^{63}$ As already discussed, crime was a favorite theme of southern Democrats

57. Barry Goldwater, "Peace Through Strength" [address 3 Sept. 1964], Vital Speeches of the Day 30 (1964): 744.

58. The ad is described in Theodore H. White, The Making of the President 1964 (New York: Athenum Publishers, 1965), 333 fn.9: "Naked-breasted women, beatniks at their revels, Negroes rioting and looting in the streets succeeded each other in a phantasmagoric film which, when shown to Goldwater, he flatly refused to authorize."

59. Transcripts and video files of campaign commercials were obtained from the American Museum of the Moving Image, The Living Room Candidate, Presidential Campaign Commercials 1952-2004, http://livingroomcandidate.movingimage.us/index. php; last accessed 4 Aug. 2007.

60. Congressional Quarterly Almanac (Washington, DC: Congressional Quarterly News Features, 1960), 701-2.

61. Goldwater, "Peace Through Strength," 746.

62. John L. McClellan, Crime Without Punishment (New York: Duell, Sloan and Pearce, 1962), 286.

63. Gerald Caplan, "Reflections on the Nationalization of Crime, 1964-1968," Law and the Social Order 3 (1973): 583-635. in expressing opposition to civil rights and integration. ${ }^{64}$

The potential explosiveness of this issue was not lost on the Johnson administration, and his aides recommended that he "immediately call a White House Law-and-Order Conference" to demonstrate their commitment to quelling violence: "I am convinced that if the president does not call such a conference, Goldwater will."65 Although his candidacy was unsuccessful, Goldwater's spirited attack laid the groundwork for extending the debate over civil rights to a ripe domain. Johnson administration officials produced a memorandum outlining steps for an extensive agenda on "crime and delinquency" shortly thereafter, primarily as a reaction to Goldwater's fevered claims: "Although there are existing Federal programs.... The obvious public concern over this matter during the campaign ... warrant a new look." "66 In March 1965, Johnson issued his first speech on crime and message to Congress-the first such presidential address specifically on crime-and sent an anti-crime program to Congress with several requests for new legislation. The most important of these, the Law Enforcement Assistance Act (LEAA), provided for a three-year pilot program of federal aid to states and localities for the purpose of innovating their criminal justice systems through training programs and experimental projects. After the bill glided easily through Congress without a negative vote, Johnson signed the LEAA, saying, "This bill puts the federal government in partnership with our states and local communities in performing the first and most important function of government: the preservation of law and order." 67

Although it was never budgeted more than $\$ 7.5$ million annually - a pittance in comparison to the criminal justice system today-"the result was a level of federal action that would have been inconceivable ten years earlier." 68 It was the first federal program specifically for the purpose of helping states strengthen their law enforcement capabilities and only the second time to that point that the federal government invested its own resources in the national crime problem. ${ }^{69}$ It was the model for several pieces

64. For a more complete discussion, see Murakawa, "Electing to Punish."

65. "Law and Order Conference," LBJ Library, JL 6 Law Enforcement-Police Matters 11/22/63-10/22/65.

66. Crime and Delinquency Memo, LBJ Library, JL 3 Criminal Matters 11/22/63-6/30/65.

67. Draft of Statement for Law Enforcement Assistance bill, 21 Sept. 1965, LBJ Library, LE/JL 6.

68. Congress and the Nation, Vol. 2: 1965-1968, (Washington, DC: Congressional Quarterly Service), 310.

69. The Juvenile Delinquency and Youth Offenses Control Act in 1961 was the first. See Congressional Research Service, Library of Congress, "The Law Enforcement Assistance Administration (LEAA): The Title I Program of the Omnibus Crime Control and Safe Streets Act of 1968, As Amended." Obtained from Lexis Nexis Congressional. 
of subsequent legislation from the Safe Streets Act three years hence to Clinton's omnibus crime control bill three decades later. It established the Office of Law Enforcement Assistance (OLEA) in the Department of Justice. While conceived with the intention of improving local law enforcement and updating practices and researching the nature of crime, it marked the beginning of an expanded federal government intervention in the area of criminal justice and law enforcement, and spawned the creation of the Law Enforcement Assistance Administration in 1968, which would ultimately dole out millions of dollars in federal aid.

However, Johnson remained dedicated to discovering the causes of crime, prevention, alternatives to incarceration, and rehabilitation. It was this end to which he established the Commission on Law Enforcement and Administration of Justice by executive order in 1965 (headed by Attorney General Nicholas Katzenbach) charged with deep investigation into these social conditions. The commission's bestselling report, The Challenge of Crime in a Free Society, blamed poverty and ghetto conditions for crime, saying "crime and recidivism cannot be cured by any correctional system so long as the roots of crime in slum living, poverty, and joblessness are allowed to persist." 70 Although the welfare approach was now balanced with a harder criminological line, most of the legislation after Johnson announced his war on crime was still rehabilitative-including civil commitment of drug addicts, prisoner rehabilitation, and juvenile delinquency-and had an intensive research focus based on two commissions to study the causes. The only punishment-based alteration of the criminal code was legislation requested by Johnson to protect civil rights workers from violent attacks. Thus, while the federal role in crime expanded quite significantly, the approach did not.

By introducing this legislation, the Johnson administration believed it was diffusing the issue; in an ironic twist, it actually served to promote it. By responding to Goldwater and endorsing an anticrime program, the administration inadvertently created a suitable context in which the crime-race argument could be reborn and flourish. The concept of federal aid to state crime programs was not altogether new. The Kennedy administration had implemented a $\$ 10$ million grant program to aid juvenile delinquency programs as part of the Juvenile Delinquency and Youth Offenses Control Act. The key distinction is that this federal aid was under the auspices of the Department of Health, Education, and Welfare "to avoid the impression of federal usurpation of a traditionally local function,"

70. United States, President's Commission on Law Enforcement and Administration of Justice, The Challenge of Crime in a Free Society: A Report (Washington, DC: Government Printing Office, 1967). while OLEA was housed in the Justice Department. Originally Senators Phillip Hart (D-MI) and Jacob Javits $(\mathrm{R}-\mathrm{NY})$ had proposed having the OLEA grants being housed under the Department of Health, Education, and Welfare (HEW).

The political arena often deals with problems, but when objective conditions pass a threshold where they become appealing and are rich in content for shifting the debate, they transcend the status to become focusing events. In the next section, I show how two crises became focusing events, opening a critical window of opportunity for issue entrepreneurs to elevate a problem to terms amenable to the defeated framework. Specifically, I show how nonracial conditions were interacted with racial ones to heighten the salience of the crime problem, associate it with racialized images, and ultimately dominate the agenda.

\section{Focusing Events: Riots and Crime}

Two crises served to elevate the status of violence as a political issue: crime and riots. Just as the Law Enforcement Assistance Act was being passed, the August 1965 riot in the Watts neighborhood of Los Angeles dealt the first blow to the poverty approach. The most destructive riot in the twentieth century up to that time ended with 36 dead, more than 1,000 injured and 4,000 arrested, nearly 1,000 buildings burned, and 15,000 National Guardsmen deployed. A U.S. News and World Report headline captured well the contention that emerged with force: "Race Friction-Now a Crime Problem? ... The turn: away from demonstrations and toward outlawry. For city after city, it's becoming a problem of crime control."71 A series of "long, hot summers" followed the events in Watts, with outbreaks in large cities to small communities, from Elizabethtown to Newark to Omaha. During 1967, 41 percent of cities with populations of more than 100,000 had experienced a racial disturbance, according to a national survey. ${ }^{72}$ Figure 4 illustrates the sharp rise in riot activity between 1965 and 1969 and the resulting arrests and injuries.

Rising black insurgency coincided with another crisis, popular perceptions of the steadily rising crime rate. By virtually every official report, media account, or political speech, crime rose in the 1960 s and continued to rise until the mid-1970s. The babyboomer generation had come of age, adding millions of youth to the population. From 1958 to 1967, the adolescent population (those aged fifteen to twentyfour) went up 42 percent, the age group that is

71. "Race Friction-Now a Crime Problem?," U.S. News and World Report, 30 Aug. 1965, 21-24, 21.

72. Cited in Virgil W. Peterson, "The Problems of Law and Order," Current History (1968): 352-56. 


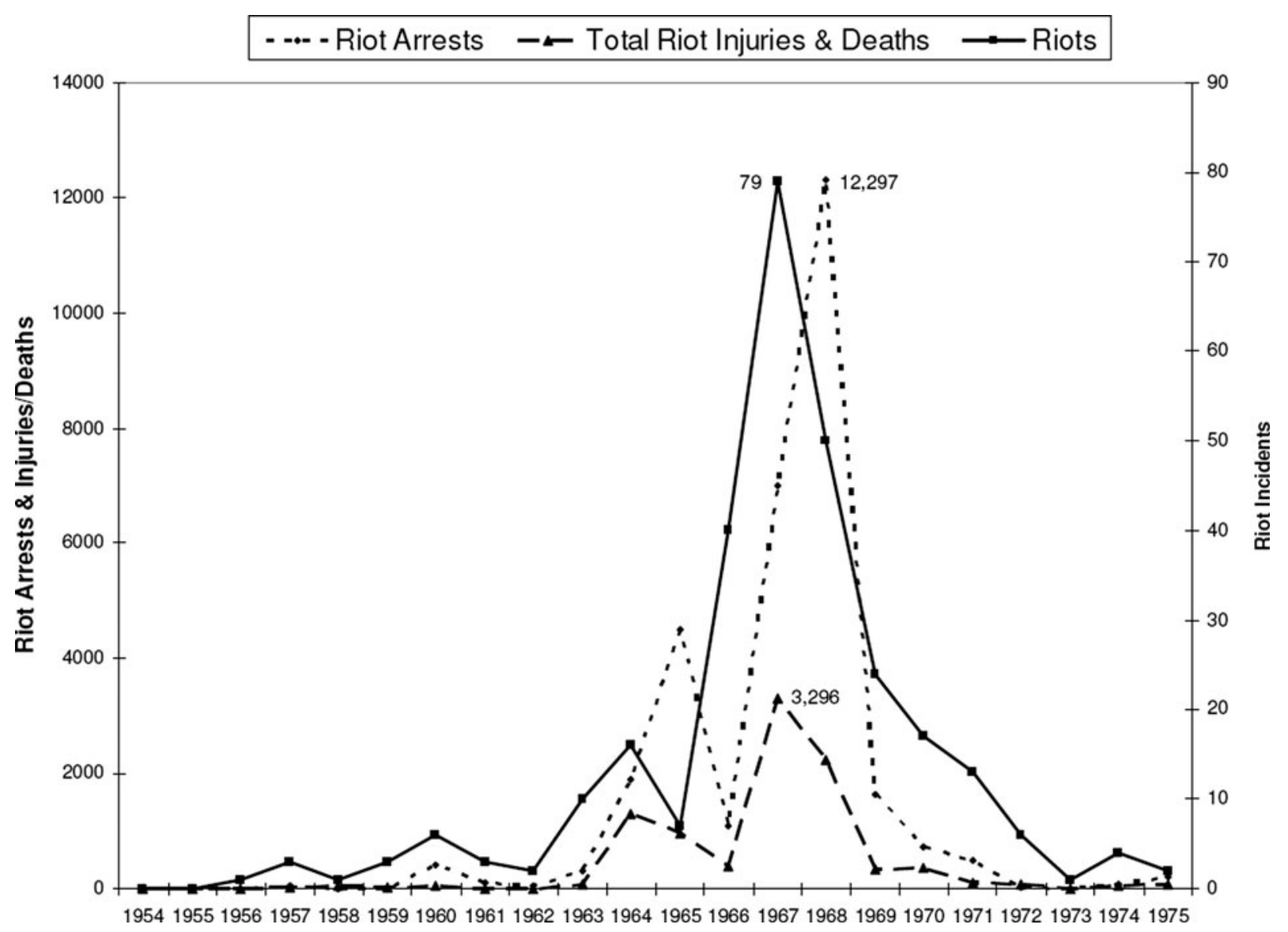

Fig. 4. Riot Incidents, 1954-1975.

Source: Based on data from Susan Olzak and Elizabeth West, "Ethnic Collective Action in Contemporary Urban United States," data from 1954-1992. NSF proposal SES-9196229. Susan Olzak and Susan Shanahan. "Deprivation and Race Riots: An Extension of Spilerman's Analysis," Social Forces 74 (1996): 931-961.

responsible for over half of index crimes, including violent offenses. ${ }^{73}$ One study found that if crime were calculated by taking into account the population in this age bracket and not the total population, the crime rate would have been stable. Simultaneously, increasing urbanization added millions to cities, which have historically experienced more crime. Figure 2 charts the trend in crime. In addition to actual rises in criminal behavior due to these natural demographic changes, there were several technical reasons for the bloated crime rates.

Crime statistics are based on the FBI's Uniform Crime Reports, compiled annually since 1930 . The reports rely on thousands of local agencies voluntarily submitting their number of reported crimes (offenses known to the police). many jurisdictions had no systematic approach to reporting these data in place prior to

73. Jerry V. Wilson, Police Report, a view of law enforcement (Boston: Little, Brown, 1975). the 1965 legislation's passing, and the proportion of those that did regularly report their crime rates increased steadily throughout the 1960s, which led to increased precision in the reports. Figure 5 charts the number of local agencies that submitted their reported crime to the FBI at least six months during the year; it steadily increases over these years, doubling from 1964 to 1985 , and closely tracks the increase in crime. In addition to inconsistent reporting, police departments had incentives not to report poor crime rates, lest they draw the critical eye of J. Edgar Hoover. This incentive to tamper could have the could have had serious effects on crime: "it is doubtful that any large city has continuously participated in the Uniform Crime Reporting [UCR] program since 1930 without there having been some purposeful, major defection from UCR standards at some time during that period." 74

74. Ibid., 14. 


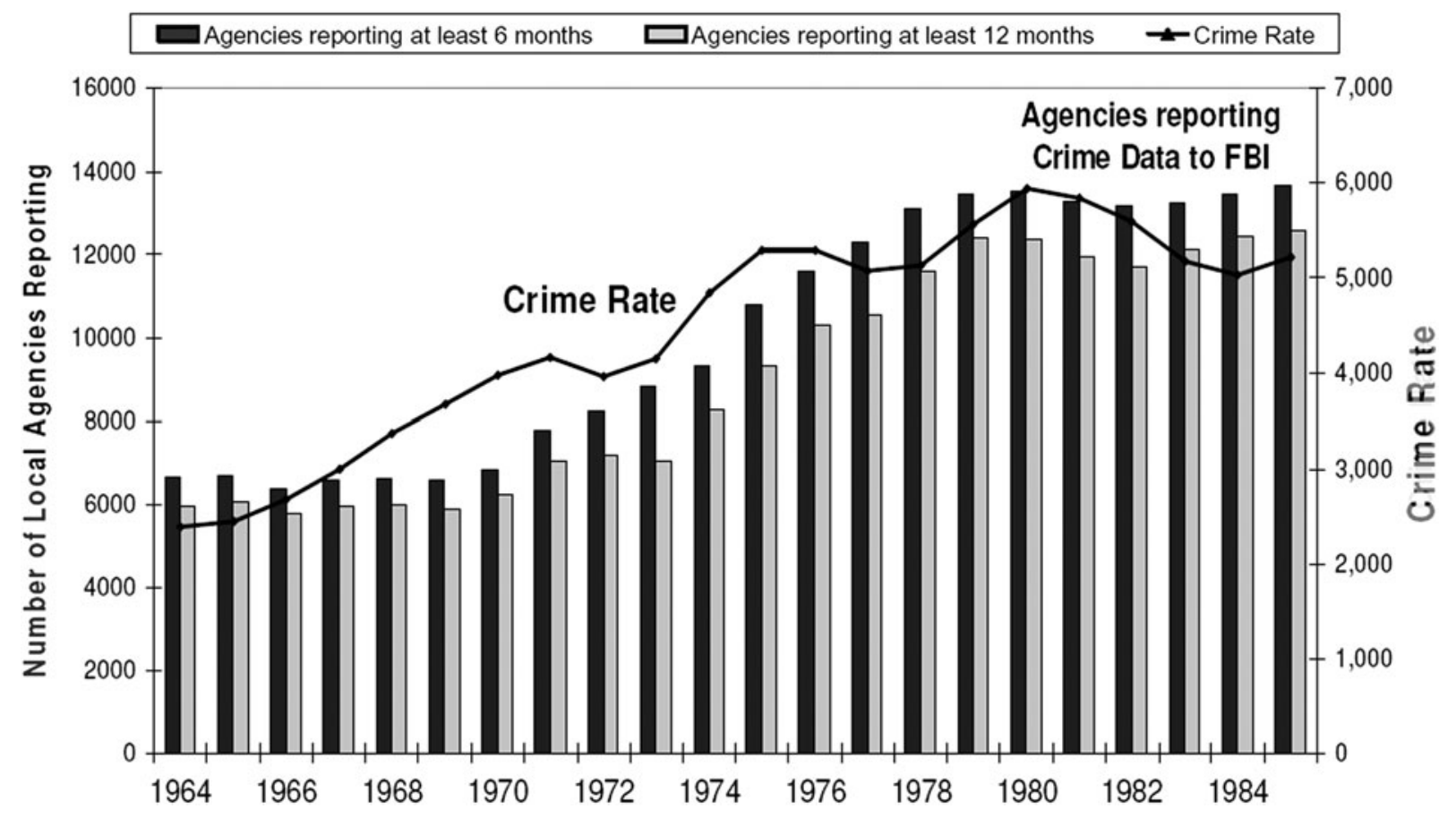

Fig. 5. Crime Reporting and the Crime Rate, 1964-1985.

Source: Data on the number of agencies that submitted crime data was provided to the author by the FBI. The total crime rate is from the Sourcebook of Criminal Justice Statistics Online.

In addition to reporting issues, the policy changes taking place in the mid- to late-1960s likely biased the historical trend in crime statistics. First, policy initiatives such as the LEAA aided the crime rate increase by professionalizing police departments, particularly rural jurisdictions, where, not coincidentally, crime rates climbed the fastest. As funds poured into local police departments and as pressure from the FBI increased, local manpower and technology for counting crimes improved dramatically. In addition to more police departments participating, the OLEA grants improved the quality of law enforcement and technologies available to them, increasing public confidence in police departments, which in turn meant that the public became more likely to report crimes during this time period. ${ }^{75}$ Second, these policies had switched the incentives of the now 40,000 police departments. Local police

75. Murray Schumach, "Crime Statistics: A Numbers Game," in Crime and Justice, ed. Ramsey Clark (New York: Arno Press, 1974), 228-29. Originally printed in The New York Times, 4 Feb. 1968.

See also President's Commission on Law Enforcement and Administration of Justice, "Crime in America," in Crime in America: Perspectives on Criminal and Delinquent Behavior, ed. Bruce J. Cohen (Itasca, IL: F.E. Peacock Publishers, 1977), 28:

This margin of unreported crime raises the possibility that even small changes in the way that crime is reported by the public to the police, or classified and recorded by the police, could have significant effects on the trend of reported crime. departments now had an incentive to inflate their crime rates because funding was contingent on need (a concern that was frequently voiced in the debates over the legislation); Attorney General John Mitchell later called this the "paper crime wave." "76 Therefore, the "official" reports were perhaps just as problematic after the passage of the 1965 Law Enforcement Assistance Act as before, but this time in the direction of overestimating crime.

People also became more likely to report certain crimes that were previously underreported, including rape. Some areas underreported crime more, particularly black neighborhoods and ghetto areas where police were reluctant to respond; greater attention to crime as a national issue and to inner-city riots ensured that a greater number of crimes in ghetto areas were recorded. Another factor contributing to artificial inclines in the rate of crime was the fact that, until 1973, the UCR counted only theft over $\$ 50$ as "larceny." 77 The largest increase in the crime rate in the 1960s was in the category of larceny, which most experts agreed was due to the declining value of the dollar combined with the unchanged $\$ 50$ that triggered a crime being reported as such. Finally, in deriving its crime statistics, the UCR used outdated census data, which led to spikes in crime

76. Wilson, Police Report, 43.

77. Indeed, larcenies can be designated as a misdemeanor or felony, depending on the state. 
at the end of the decade because population counts, the denominator, remained unchanged until the next census. $^{78}$

Taken together, these factors resulted in estimates that were likely biased toward increasing trends, reflecting improvements in crime reporting rather than a scourge of crime. A combination of the vagaries of counting across disparate local law enforcement agencies, professionalizing at different paces, with the demographic realities of increasing urbanization and the baby boomer generation meant that finding the truth about the rise in the crime rate was nearly impossible. However, despite the large statistical nightmare that it presented, the fact of a crime epidemic was no longer disputed by 1965, and a steady flow of reports and journalistic accounts ensured that it was communicated to the public. Paradoxically, in addition to other exogenous factors, LEAA's passage in 1965 ensured the appearance of rising crime rates-the fodder which combined with escalating riot-related violence in the cities was used to call for more, and more draconian, policies.

The convergence of these critical factors altered the opportunity for establishing political advantage; elites leveraged these events to define a new issue, associate it with certain images and ultimately secure a monopoly on the issue understanding. The riots gave a rising crime rate new political currency. Mediated by elite goals, these conditions ripened the possibility of forming a new issue and increased the public receptivity to the original argument voiced in civil rights debates.

\section{Problem Definition: Racializing Crime, Criminalizing Racial Struggle}

The frontlash relied on a two-stage maneuver. First, conservatives attached civil rights to lawlessness by arguing that civil disobedience flouted laws and would inevitably lead to more lawless behavior. Thus, nonviolent protest was connected to riots. But then, through a reverse claim, they disconnected the relationship they had just sewn, by arguing that the riots were not connected to legitimate grievances but to "crime in the streets."

Old habits did die hard; previously confined to debates around civil rights, the arguments linking crime and civil rights were ultimately revived and inserted into debates around crime, but this time with more sophistication and aided by real-world conditions. Early opponents of civil rights legislation had argued that one form of civil rights protest would ultimately lead to more law-breaking and that civil rights and voting rights legislation would reward such lawlessness. The new norm of racial

78. Daniel Bell, The End of Ideology: On the Exhaustion of Political Ideas in the Fifties: With a New Afterword (Cambridge, MA: Harvard University Press, 1988), esp. chap. 8. equality required that proponents avoid the explicitly racist justifications of its Jim Crow predecessor. Instead, supporters of punitive crime legislation now argued that civil rights strategies promulgated the idea that laws could be obeyed selectively. With the nation engulfed in violent protests, they reopened this argument to legitimize their attack on the civil rights agenda and initial appeals for heavier handed law enforcement.

The strategy relied on two mutually reinforcing elements: (1) depoliticization and criminalization of racial struggle and (2) racialization of crime. According to this argument, the civil disobedience strategy of movement activists was the major culprit in the crime increase. ${ }^{79}$ This claim was empirically unfounded; though arrests related to collective action protests did increase during this time, it was not of a scale to make the aggregate crime rate increase. ${ }^{80}$ Some academics believe collective action actually had the opposite effect. $^{81}$ But in their advocacy, proponents of the new doctrine championed the view that civil rights demonstrations amounted to violence and created a climate of lawlessness. Senator Richard Russell denounced politicians for condoning them:

The seeds that have been sown by high officials encouraging violations of local law are now producing the crop of violence .... If our highest officials continue to applaud sit-ins, lie-ins, stand-ins, and all other violations of property rights, it can lead us into a state of anarchy. ${ }^{82}$

\section{Goldwater had used this rationale early on:}

But no one can in deep conscience advocate lawlessness in seeking redress of a grievance! When men will seek political advantage by turning their eyes away from riots and violence, we can well understand why lawlessness grows even while we pass more laws. (Goldwater, "Peace Through Strength", 746)

80. Because the Uniform Crime Report statistics do not separate out those behaviors related to mass demonstrations and riots, it is difficult to know exactly what proportion of the crime rate was attributable to the racial disorders. The government's investigation of riots and major civil disorders counted 59,257 related arrests during the three year period of 1965-1968 (U.S. Senate Permanent Subcommittee on Investigations of the Committee on Government Operations, Staff Study of Major Riots and Civil Disorders-1965 Through July 31, 1968. $90^{\text {th }}$ Cong., $2^{\text {nd }}$ sess., Oct. 1968). The President's Commission on the Causes and Prevention of Violence credited group political activity as a major cause in the increase in crime. According to the Commission, there were 71,000 arrests related to demonstrations, protests, and riots between 1963 and 1968; to compare, homicides generated 39,000 arrests during the same time span (U.S. National Commission on the Causes and Prevention of Violence, To Establish Justice, To Insure Domestic Tranquility: Final Report [Washington, DC: Government Printing Office, 1969]).

81. Frederic Solomon, "Civil Rights Activity and Reduction in Crime among Negroes," in Problems and Prospects of the Negro Movement, ed. Raymond J. Murphy and Howard Elinson (Belmont, CA: Wadsworth Publishing Company, 1966).

82. Sen. Richard B. Russell in "Crisis in Race Relations-How Will It Be Met? Interviews with Congressmen around the Nation,” 27. 
The argument depended on collapsing the distinction between political protest, which relied on a strategy of nonviolence, with riots; Herman Talmadge (D-GA) concluded that "mob violence such as we have witnessed is a direct outgrowth of the philosophy that people can violate any law they deem to be unjust or immoral or with which they don't agree." ${ }^{83}$ Senator Russell Long gave a speech explaining where the riots started"When Martin Luther King was in the Birmingham, Alabama, jail and wrote a letter ... to the preachers which said civil disobedience is OK if done in the name of civil rights." ${ }^{84}$ J. Edgar Hoover also denounced the nonviolent strategy of civil rights activists:

\begin{abstract}
"Civil disobedience," a seditious slogan of gross irresponsibility, has captured the imagination of citizens .... I am greatly concerned that certain racial leaders are doing the civil rights movement a great disservice by suggesting that citizens need only obey the laws with which they agree. Such an attitude breeds disrespect for the law and even civil disorder and rioting. ${ }^{85}$
\end{abstract}

One of the most articulate proponents of this idea was the former Supreme Court Justice Charles E. Whittaker, who, since retiring from the Court, traveled across the country giving speeches and often testified before Congress mainly on this point. ${ }^{86}$

Therefore, even though most protest was still nonviolent, by arguing that civil disobedience violated the rule of law and led to more serious lawlessness, it was violent, and thus, criminal. Thus, the counterproject contended that racial struggle, both peaceful and violent, was inherently criminal. But, for racial disorder to successfully be attached to criminality, a second supporting idea was required.

83. Sen. Herman E. Talmadge, in ibid., 29.

84. Marvin Watson to President Johnson. 2 Aug. 1967 (6:20 PM), LBJ Library, HU2, 7/30/67-8/8/67.

85. J. Edgar Hoover, (1965), 72.

86. In discussing the "current rash and rapid spread, of planned, mass violation of our laws," Whittaker blamed "Negro leaders" for telling the "Negro masses" that,

$[\mathrm{T}]$ hey should go forth and 'force' the whites to grant them their 'rights', and, in doing so they should violate the laws that stand in their way because they are 'bad' laws-which is plainly to tell them to take the laws into their own hands and to judge for themselves, as they proceed, which of them they will obey and which of them they will violate. In that angry mood, and with that advice, they do go forth .... as if looking for trouble-and frequently so block the walks, streets, parks, and highways as to preclude their intended public uses ... and, when those violations of our laws are resisted, even by the police, open riots usually break out and result in commission by them of crimes of moral turpitude. (Charles E. Whittaker, "Planned, Mass Violations of our Laws: The Causes, and the Effects Upon Public Order" [address 14 Feb. 1967], Vital Speeches of the Day 33 [1967]: 324).
Just as important as what conservative strategists associated with racial discord, is what they disassociated from it. In order to discredit the idea that violent racial struggle was an outcome of social conditions, conservative strategists became preoccupied with showing that racial discord was neither motivated by police brutality nor did its origins emanate from racial discrimination; rather, it was criminality, pure and simple. For example, though looting was a form of protest, usually targeting discriminatory businesses, looters were depicted as criminals who pursued their loot in a "holiday spirit." Even while the National Commission on Civil Disorders reported findings that most racial disorders were instigated by confrontations between the local community and police and/or alleged excessive police force, many legislators and public commentators construed them as being perpetrated by professional agitators, Communist Party affiliates, and self-serving looters, hoodlums, and criminals. According to one "top authority," Los Angeles Police Chief William Parker, the "police brutality" allegations were a "terribly vicious canard which is used to conceal Negro criminality ... to try to find someone else to blame for their crimes." ${ }^{87}$ In his statement before the Crime Commission, J. Edgar Hoover, the highest ranked U.S. law enforcement official, dismissed police brutality as part of a communist campaign, stating that the "net effect of the charge of "police brutality' is to provoke and encourage mob action and violence by developing contempt for constituted authority." 88 Indeed, Hoover's report on the 1964 riots concluded that, because civil rights agencies had not received formal complaints prior to the riots, they could not have been sparked by racial discrimination or police misconduct and went on to applaud the police for performing very well. ${ }^{89}$

They also refuted arguments that riots were outbreaks against impoverished conditions. If poverty were the cause, they argued, then why were the cities that were the best for blacks being victimized? This sentiment was echoed frequently. As Senator Robert Byrd (D-WV) argued:

So, Mr. President, ... [p] overty neither provides a license for laziness nor for lawlessness. We can take the people out of the slums, but we cannot take the slums out of the people. Wherever some people go, the ratholes will follow.... All the housing and all the welfare

87. "Race Friction-Now a Crime Problem?," 23.

88. Federal Bureau of Investigation, "Statement of J. Edgar Hoover Before National Commission on the Causes and Prevention of Violence, September 18, 1968," 6.

89. Federal Bureau of Investigation, Prevention and Control of Mobs and Riots (Washington, DC: n.p., 1967). 
programs conceivable, will not stop the riots or do away with the slums. ${ }^{90}$

Nor was racial discrimination a factor. After Watts, California Governor Edmund G. Brown declared: "The riot had no connection with whether a Negro has the right to vote or a legal right to any job for which he can qualify. We have established these things in California."91 The McCone Commission, charged with analyzing the causes of the Watts riot, blamed the rioting on blacks, calling it a "formless, quite senseless" explosion and denied any role of the police in the agitation. ${ }^{92}$ According to one Evening Star editorial, "A man who makes a firebomb and throws it through a shop window is not doing it because his grandfather was a slave.... Those who openly advocate wanton acts should be severely punished." 93 Others argued that police actions were legitimate responses to the behavior of black residents; for instance, Senator Byrd said that "If they [blacks] conduct themselves in an orderly way, they will not have to worry about police brutality." 94 Surveys of public opinion demonstrate that this campaign to disassociate police actions from racial unrest was very successful: a mere 13 percent of the public believed "police brutality" was a cause of the riots. ${ }^{95}$

A third image in the frontlash strategists' toolkit was focused on enlisting popular rights-language to their cause. Politicians counterbalanced civil rights claims with criminal justice. The focus on civil rights had gone too far, the argument went, and was permitting the rights of society from protection against criminals and agitators to be sacrificed. For example, in a letter to President Johnson, Representative L. Mendel Rivers (D-SC) noted: "The Nation cries out for leadership; fear permeates the air; insurrections runs rampant; law and order is on the verge of total collapse. ... Now is the time to speak of obligations-not rights."96 Pitting the priorities of crime and civil rights against each other, another advocate, Georgia Governor Lester Maddox, wired the president in 1967:

I advised you on numerous occasions starting in early 1964 that national legislation... would bring waves of violence, burning, looting, injury and violent death ... Please do

90. "Poverty: Phony Excuse for Riots? 'Yes,' Says a Key Senator," U.S. News and World Report, 31 Jul. 1967, 14.

91. "Race Friction-Now a Crime Problem?," 22.

92. Joe R. Feagin and Harlan Hahn, Ghetto Revolts: The Politics of Violence in American Cities (New York: Macmillan Publishing Co., 1973).

93. Repr. in Congressional Record, 3 Aug. 1967, H9932.

94. "Poverty: Phony Excuse for Riots?," 14. 255.

95. "81\% In a Poll See Law Breakdown," in Crime and Justice,

96. Telegram to the President from L Mendel Rivers, Member of Congress, 25 Jul. 1967, LBJ Library, HU 2 7/1/67-7/28/67; emphasis added. not urge additional legislation that strikes down the right to private property, free enterprise .... Please offer no more programs that are nothing more than attempted bribes to buy law and order and good behavior. ${ }^{97}$

To symbolize the priority of crime over civil rights, Representative Craig Hosmer (R-CA), introduced a proposed constitutional amendment: "The right of society in general and individual persons in particular to be protected from crimes against person and property shall be paramount to other rights." 98 In 1968, Richard Nixon would proclaim that the "first civil right" was the "right to be free from violence." 99

Politicians linked civil rights and crime through implicit appeals. Although they avoided explicitly racist exhortations about racial integration breeding crime, they associated the problem of crime with racial change, radicalism, and civil rights demonstrations. Republican leader of the House Gerald Ford gave an emphatic statement to the press:

\begin{abstract}
The War at home-the war against crime-is being lost.... The homes and the streets of America are no longer safe for our people. This is a frightful situation .... The Republicans in Congress demand that this Administration take the action required to protect our people in their homes, on the streets, at their jobs .... When a Rap Brown and a Stokely Carmichael are allowed to run loose, to threaten law-abiding Americans with injury and death, it's time to slam the door on them and any like them-and slam it hard! ${ }^{100}$
\end{abstract}

Seeking issue dominance, conservative entrepreneurs presented a set of ideas around the crime problem favorable to their goals: there was a growing tide of lawlessness; civil disobedience led to violent riots; riots were not a legitimate grievance but were criminal acts; the right of society to be free from criminals was above rights of protesters (who were criminal); therefore, we need more punishment. This issue framing was sanitized from collapsed logics of segregation and superiority, while putting forward a coherent statement of why the old root causes position was part of the new problem.

So, like its antecedent in civil rights debates, crime was linked to civil rights. But this time argument not to oppose civil rights but to proactively call for law

97. Telegram to the President from Lester Maddox, Governor of Georgia. 12 Apr. 1968, LBJ Library, JL 3.

98. Right to Protection From Crime Should be Paramount, $89^{\text {th }}$ Cong., $1^{\text {st }}$ sess., Congressional Record 111, pt. 1624 Aug. 1965, 21646.

99. Richard M. Nixon, "Toward Freedom from Fear," speech read into $90^{\text {th }}$ Cong., $2^{\text {nd }}$ sess., Congressional Record 114, pt. 10, 13 May 1968, 12938.

100. Qtd. in James L. Sundquist, Dynamics of the Party System: Alignment and Realignment of Political Parties in the United States (Washington, DC: Brookings Institution Press, 1983), 385. 
enforcement. From 1965 to 1969, nearly 100 pieces of legislation made participating in a riot a federal offense with stiff penalties. ${ }^{100}$ The 1968 Omnibus Crime Control and Safe Streets Act made it a felony to cross state lines with the intent of inciting or taking part in a riot; another provision banned people convicted of a riot-related felony from federal employment and from receiving federal money. ${ }^{102}$ The 1967 District of Columbia Crime Bill also contained an anti-riot provision that gave penalties of up to five years imprisonment and fines of up to $\$ 10,000$ for engaging in, inciting, or encouraging others to participate in a riot. ${ }^{103}$ In addition to numerous crime-related bills, riot-related penalties and provisions also surfaced as riders to civil rights bills, including the 1966 and 1968 Civil Rights Acts. For example, the liberal open housing law of 1968 contained a tacked on antiriot bill (sponsored by Representatives Strom Thurmond [R-SC] and Frank J. Lausche $[\mathrm{D}-\mathrm{OH}])$, or the "H. Rap Brown bill," as it was termed after the Black Power leader. ${ }^{104}$ Congress included antiriot provisions in several other bills unrelated to crime that banned students and federal employees convicted of riot offenses from receiving federal money. Even a "routine postal salary bill" contained provisions banning from federal employment any person convicted of an offense related to a riot or civil disorder. ${ }^{105}$ Similarly, at least twenty states revised their criminal codes to include riot offenses, with most carrying prison sentences. ${ }^{106}$ In 1969 alone, state legislatures proposed more than 100 separate riot-related bills. ${ }^{107}$

\section{The Liberal Dilemma}

The conservative countermovement thus presented a coherent problem definition based on depoliticizing and criminalizing the riots and racializing crime. This set of images created political traps for liberals. As they had in civil rights debates, liberal voices

101. Murakawa, "Electing to Punish."

102. See section on "Riots and Federal Workers" in CQAlmanac 1968,641 .

103. U.S. House Committee on the District of Columbia, AntiRiots Hearing before Subcommittee No. 4, $90^{\text {th }}$ Cong., $1^{\text {st }}$ sess., 1967.

104. The resulting bill was much more expansive than the one proposed by Johnson and the Kerner Commission. The anti-riot bill ultimately passed because the fair housing bill rested on a fragile coalition of votes.

105. CQ Almanac 1968, 641. The provision was later deleted when the sponsor argued that it was a "product of hysteria."

106. Feagin and Hahn, Ghetto Revolts.

107. Richard Harris, Justice: The Crisis of Law, Order, and Freedom in America (New York: E.P. Dutton, 1970). In one of the more extreme examples, the Virginia legislature debated a bill that would have "permitted authorities to form a posse to deal with rioters when authorities merely expected a riot" (Virginia House Bill No. 365, 18.1-254.10 [1968]). See also M. Cherif Bassiouni The Law of Dissent and Riots (Springfield, IL: Charles C. Thomas, 1971). recognized the strategy of linking civil rights agendas to the problem of crime and tried to expose its racial character. The Washington Post headline characterized the allegation of liberals and black leaders: "Crime in Streets' is Called Slogan to Curb Negroes."108 Attorney General Nicholas Katzenbach was wary of the public hysteria that was being created around increasing crime statistics and their implied connection to the violent destruction being depicted on televisions throughout the country:

\section{The [Civil Rights] Act, they say, has encouraged disrespect for the law in other parts of the country. Thus, a link is drawn between demon- strations for civil rights and crime in the streets. Riots in Harlem, or Rochester, or Philadelphia, are tied to rising crime rates. ${ }^{109}$}

Presidential candidate Hubert Humphrey similarly argued:

\section{Segregationists and some white conservatives use the riots as an excuse not to take the action for racial justice that they do not support anyway. They are very much afraid we will "reward the rioters," as they say .... Ever since Watts, and particularly since Detroit and Newark, the discussion of equal rights has been distorted and sometimes even side- tracked by the very different issues of riots and civil disorders, of "crime in the streets' and "law and order." ... It is dangerous non- sense to believe that social progress and a respect for law are somehow in opposition to each other. ${ }^{110}$}

However, because the new conservative doctrine had worked vociferously to conflate crime and civil disobedience, with its obvious extensions to civil rights, liberals were forced to walk a tightrope. The liberal position was wedged in a trap-either refute the conservative paradigm, arguing that riots were legitimate expressions of deplorable inner-city conditions, which risked the appearance of sanctioning violence and doing permanent damage to the civil rights agenda, or seek to avoid blame for the riots by presenting a strong case for their distinction from civil rights protest. They pursued the latter strategy.

Liberals tried to project the message that riots were not part of a legitimate articulation of racial discrimination, for fear that the violent nature would hurt their civil rights agenda and create a backlash among previously supportive groups of whites. Black leaders submitted a collective statement printed in the New York Times in 1964 distinguishing between

108. Jean M. White, “'Crime in Streets' Is Called Slogan To Curb Negroes," Washington Post, 23 Jan. 1968.

109. Nicholas deB. Katzenbach, "The Civil Rights Act of 1964," Vital Speeches of the Day 31 (1964): 27.

110. Hubert H. Humphrey, Beyond Civil Rights: A New Day of Equality (New York: Random House, 1968), 133. 
rioting and "legitimate protest."111 In 1966, another group of nationally prominent black leaders, including A. Philip Randolph, Dorothy Height, Bayard Rustin, Roy Wilkins, and Whitney Young, Jr. published a statement in the New York Times repudiating violence while endorsing criticism of poor conditions in the ghettos. ${ }^{112}$ LeRoy Collins, formerly the head of the Community Relations Service of the DOJ, also tried to distinguish riots and protest: "We don't want to associate civil rights with this kind of lawlessness." And Attorney General Nicholas Katzenbach: "To call them [riots] 'racial' problems is not a solution but a slogan. What is worse, it is wrong." $" 14$ President Johnson put the point more bluntly: "A rioter with a Molotov cocktail is not fighting for civil rights any more than a Klansman with a sheet on his back and a mask on his face." ${ }^{115}$ By making these claims, liberals implicitly argued that the urban violence was not part of a larger social ill and that riot participants were common criminals, confirming the conservative claim.

The conservatives had offered an uncompromising position on crime and lawlessness. In contrast, the liberal alternative was to mix the call for law enforcement with more sobering pleas for social uplift. At a meeting called "Order and Justice" in September 1968, one participant characterized the conundrum: "We can't compete with Nixon and Wallace on law and order. But we're going too far on the justice emphasis. Let's emphasize order and justice."116 Ultimately, this emerged as the liberal alternative in an attempt to counter the popular conservative slogan with their own moniker- "law and order with justice," an ambiguous position that tried to serve two masters. Liberal leaders tread this thin distinction, arguing that while we must act against violence and "put down" riots, there must also be consideration for continued progressive measures toward equality and programs to lessen unemployment and poverty. This message was not easily accessible to the public and stood in stark contrast to the seamless conservative message. The incoherent position left liberals precariously straddled across two sides that were increasingly polarizing. Conservative Republicans and southern Democrats attacked this alternative with the appeal that liberal politicians were permitting criminality to flourish under the guise of poverty and disenfranchisement, camouflaging ordinary crime as dissent, and "pussyfooting" on the

111. "Texts of Statements by Negro Leaders," New York Times, 30 Jul. 1964, 12.

112. Repr. in Crisis and Commitment, $89^{\text {th }}$ Cong., $2^{\text {nd }}$ sess., Congressional Record 112, pt. 20, 17 Oct. 1966, 27189-90.

113. Qtd. in "Race Friction-Now a Crime Problem?," 24.

114. Katzenbach, "Civil Rights Act of 1964," 27.

115. Lyndon B. Johnson quoted in "Shift in the wind in Washington [violent defiance of law and order gone too far]," U.S. News E World Report, 6 Sept. 1965, 28.

116. Transcript, Lawrence F. O'Brien Oral History Interview 26, 26 Aug. 1987, by Michael L. Gillette, Internet copy, LBJ Library. issue of crime and riots. Nixon exposed this weakness in his "Toward Freedom from Fear" speech:

\begin{abstract}
There is another attitude that must be discarded if we are to wage an effective national war against this enemy within. That attitude is the socially suicidal tendency-on the part of many public men-to excuse crime and sympathize with criminal because of past grievances the criminal may have against society. ${ }^{117}$
\end{abstract}

Republicans launched a harsh criticism of the Democrats in their 1968 pamphlet entitled "Crime and Delinquency-A Republican Response." Among the many criticisms, one of their strongest was against the Great Society approach: "The Johnson-Humphrey Administration has proposed its standard 'great society' answer to the problem-Federal money and Federal controls ... but too many factors indicate that improved economic and social conditions alone will not reduce crime." 118

Had the crime problem not been accompanied by riots and racial unrest, a root causes approach might have been favored, as the direction of the $1950 \mathrm{~s}$ suggested, and the crime-race argument that racial conservatives employed would have been easily exposed as a racial ruse. Wracked by riots, the terrain had become hostile to the liberal root causes position-or, as Hoover maintained, society was "beginning to gag on the steady sociological diet of excusing the conduct of teenage hoodlums because 'society has failed them'."119 The Democrats were split between holding fast to this position and moving rightward, while conservatives were unified. As civil rights was increasingly tied to criminality, the costs of defending civil rights and claiming poverty and unemployment as causes of riots was becoming clearly felt. Liberals engaged in strategic agreement, endorsing the conservative issue definition and policy program (see Figure 6).

Ultimately, liberals betrayed their early solidaristic calls for social reform and warring on poverty and, by the end of the 1960s, they began downplaying underlying causes, arguing instead for more gun control. Not in small part due to several defeatsDemocrats had lost 12 million voters between 1964 and 1968 - the early emphasis on poverty and social conditions faded. By 1968, Democrats had aligned themselves with the "law and order" program and were trying desperately to mimic the Republicans. The Democratic platforms during this time period demonstrate how increasingly indistinguishable their position was from the Republicans. The Democratic

117. Nixon, "Toward Freedom from Fear," 12936.

118. Task Force on Crime and Delinquency [prepared under the direction of the Republican National Committee], Crime and Delinquency-A Republican Response (Washington, DC: 1968), 4-24.

119. "People of the Week-And a Warning from J. Edgar Hoover,” U.S. News EF World Report, 13 Sept. 1965, 20. 


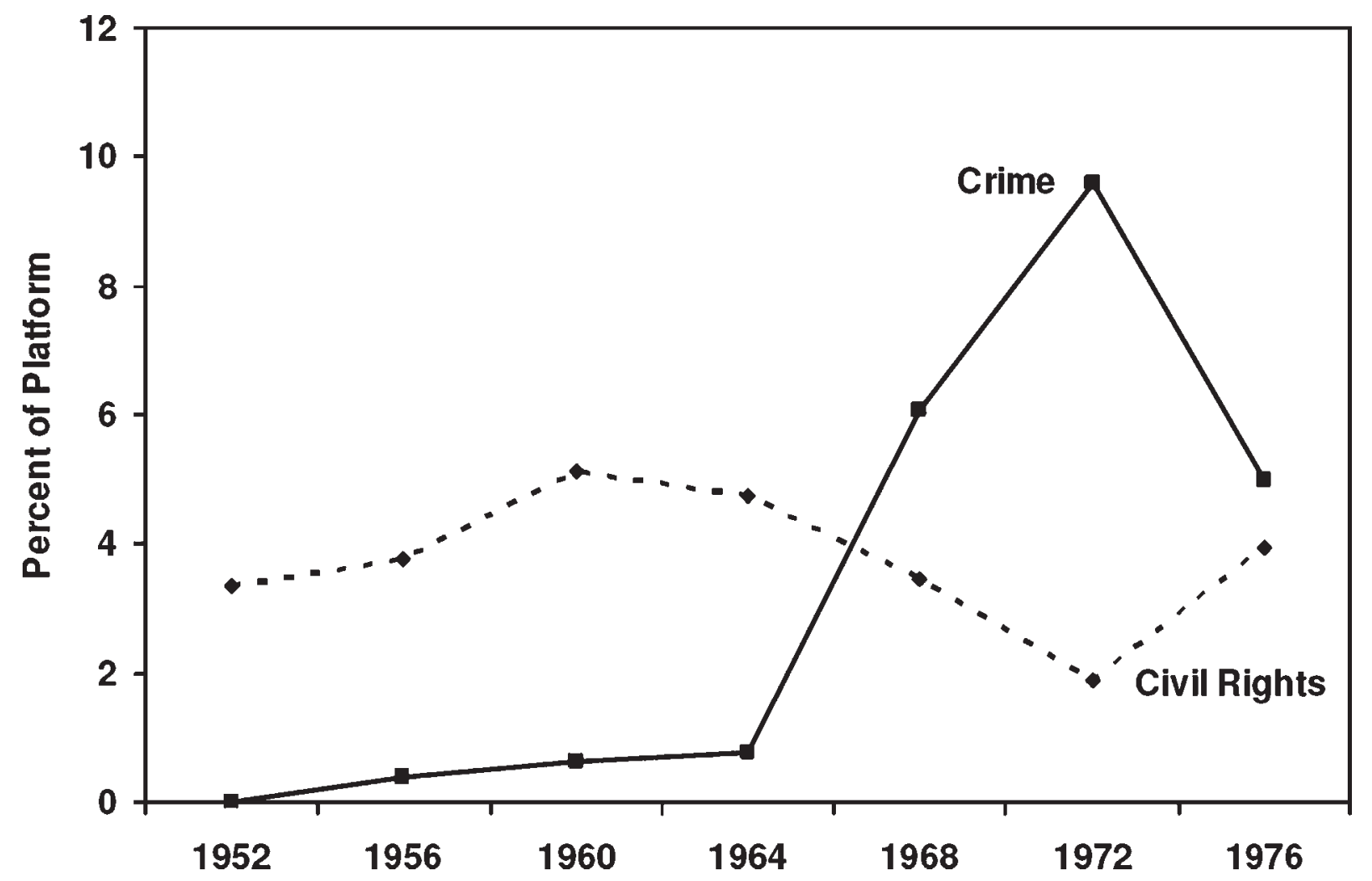

Fig. 6. Democratic Party Agenda on Civil Rights and Crime.

Source: Author's compilation. Text of the party platforms was from the Public Papers of the Presidents, available in digital format: John Woolley and Gerhard Peters. The American Presidency Project [online] (Santa Barbara, CA: University of California [hosted], Gerhard Peters [database]). Available at http://www.presidency.ucsb.edu/ (last accessed 6 Aug. 2007).

platform in 1956 contained a mere three sentences on law enforcement; the 1960 platform included only one additional sentence (dealing specifically with organized crime). By the next election, the issue was beginning to rise in importance: "We cannot and will not tolerate lawlessness. We can and will seek to eliminate its economic and social causes." While crime is no longer ignored, the platform also firmly set out the idea that through eradicating poverty, crime would likewise diminish. The only mention of stricter punishments was focused on the unlawful behavior of employers who discriminate. The 1964 platform highlighted two pieces of legislation-the Juvenile Delinquency and Youth Offenses Control Act of 1961 and the Criminal Justice Act of 1964 - that were aimed at preventing youth crime and making sure poor people were adequately represented in court, respectively. By 1968, the Democratic Party was clearly beginning to recognize the costs of being seen as supporting lawbreakers and the root causes commitment had faded. The program included a much fortified discussion on the problem of crime and strong critique of dissenters who use violence and pledged a "vigorous and sustained campaign against lawlessness in all its forms."
Meanwhile, Robert Kennedy campaigned for the Indiana primary by voicing his opposition to crime and Humphrey sought the Minnesota primary on law and order.

By the 1970s, the root causes argument had been eliminated in favor of echoing and reinforcing the connection between crime and civil rights, rendering Democrats virtually indistinguishable from their conservative counterparts. For one example, Senator Ted Kennedy (D-MA) echoed the conservative line: "Along with the civil right to vote, go to school, and have a job is the right not to be mugged, robbed, or assaulted." ${ }^{120}$ Polls suggest that, by 1970, people viewed the two political parties as roughly equivalent on crime control. In response to one Gallop survey question on the issue — "which party-the Republican or the Democratic-do you think can do the better job of dealing with crime and lawlessness?"- the majority of respondents saw no difference or had no opinion (44 and 11 percent, respectively), while only 4 percent more respondents believed the

120. Qtd. in Cronin, Cronin, and Milakovich, U.S. v. Crime in the Streets, 177. 
Republican Party would do a better job on crime than the Democratic Party (24 and 20 percent, respectively). ${ }^{121}$

When policy images are accepted and one side develops a monopoly on the understanding of an issue, they constrain the policy choices available. In the next section, I offer a detailed account of the way the problem definition and process of strategic pursuit manifested itself in crime laws. Not only did the liberal approach begin to come apart at the seams, administration proposals would again and again collide into a conservative-controlled committee. Constrained by public opinion, many liberals in Congress admitted to voting for some legislation to prevent other, more punitive legislation from passing.

\section{Establishing a Monopoly: The Ascendance of Law and Order}

After the "long, hot summer" of 1967, where riots occurred in 120 cities, it seemed the "Great Society" had given way to lawlessness. By the end of that summer, there had been at least 150 violent racial disorders spread across 128 cities, resulting in 118 dead, 4,000 injured, about 10,000 arrests, and millions of dollars of property damage. ${ }^{122}$ The National Guard had been mobilized twenty-three times and on one occasion U.S. Army troops were deployed. Many perceived the nation as gripped in a state of rebellion (Figure 7).

At the same time, the public believed they were beleaguered by crime. Crime and lawlessness was the top issue to the public in 1968 for the first time since the 1930s, according to the Gallup poll, and about half of the public believed crime was increasing (compared to only 3 percent who said decreasing).123 The next year, 88 percent of people felt that the problem of "crime in the streets" should have a "great deal of attention paid to it (Figure 7)."124

By the time the National Advisory Commission on Civil Disorders (commonly known as the Kerner Commission) issued its report in 1968, the "end poverty and discrimination" appeal fell on deaf ears. Not only was it no longer an approach to crime and an excuse for permissiveness, some in Congress argued that further aid to ghettoes would capitulate to the riots; many assistance programs were cut including the rent supplement program, or dwindled down like the Model Cities program. The Kerner Report warned that without social reform, the riots

121. The Gallup Poll no. 797, Jan. 1970.

122. "Era of Growing Strife in U.S.,"U.S. News E W World Report, 25 Sept. 1967, 42.

123. Louis Harris and Associates, The Public Looks at Crime and Corrections: Report of a Survey Conducted for the Joint Commission on Correctional Manpower and Training in November, 1967 (Washington, DC: Joint Commission on Correctional Manpower and Training, 1968). 124. Harris Study no. 1970.

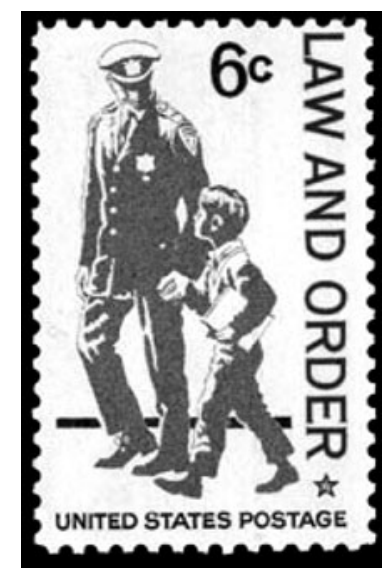

Fig. 7. Law and Order postage stamp.

Note: Special stamp issued in 1968 (unveiled at the White House on May 17, 1968).

would only get uglier and incorporate mainstream blacks. ${ }^{125}$ One of its authors, New York City Mayor John Lindsay warned: "The only certain change will be that next summer, all of it will be worse-more festering, more inflamed, and infinitely more perilous." ${ }^{26}$ The Kerner Report was heavily criticized for blaming mobs and violence on white racism. Conservatives in the Senate Committee on Government Operations introduced a resolution to conduct their own investigation of "crime and lawlessness" sponsored by John McClellan:

\begin{abstract}
Although the committee recognizes and commends the action taken by the President in appointing a Special Advisory Commission on Civil Disorders, it is the consensus of the Rules Committee members that the spate of riots and civil disturbances which have occurred throughout the Nation during the last few weeks places a corollary responsibility on the Senate to conduct its own investigation. ${ }^{127}$
\end{abstract}

There were still those who argued that an attack on poverty was the means through which crime should be thwarted, but they were now in the minority. John Sherman Cooper (R-KY) proposed an amendment (which was ultimately rejected) to the Senate resolution to incorporate a "study and investigate the extent to which economic or social causes have bearing on such disorders, the community attitudes

125. United States, National Advisory Commission on Civil Disorders, Report of the National Advisory Commission on Civil Disorder (Washington, DC: Government Printing Office, 1968).

126. John V. Lindsay, "Violence in the Cities," Vital Speeches of the Day 33 (1967): 676.

127. U.S. Senate, Authorizing the Committee on Government Operations to Investigate Crime and Lawlessness within the United States: Report together with Individual Views to Accompany S. Res. 150, $90^{\text {th }}$ Cong., $1^{\text {st }}$ sess., 1967, rept. 470, 2. 
toward such causes," and urging the other senators to "consider also their grievances, their conditions, and that the Congress intends to move urgently to correct them." 128 Southerners held key positions on both the District of Columbia Crime Committee and the Judiciary Committee and conservatives dominated the Senate Subcommittee on Criminal Procedure, which was chaired by John McClellan. Ramsey Clark noted that McClellan was "so terribly strategically located":

\begin{abstract}
He was chairman of the Subcommittee in Judiciary, the second ranking man on the Judiciary, had the complete support of the chairman, Senator Eastland. He was also the chairman of our Appropriations Subcommittee so that literally on occasion we would adjourn a subcommittee meeting on the authorization ... and Senator McClellan wouldn't even get up out of his seat. ${ }^{129}$
\end{abstract}

Realizing that the riots were costing him votes, several of Johnson's advisors pushed the president to "start acting less like a social worker and more like a cop." 130 However, they also saw the potentially disastrous consequences of promising the public more than it could deliver on crime and riots: "it is very important not to identify crime as a Presidential problem but as a local problem he is helping Governors and Mayors to solve .... So let's not do anything to raise crime's rating as a national problem." 131 Turning his back on recommendations from Warren Christopher and Ramsey Clark, Johnson instructed Joe Califano to include a riot bill in his upcoming crime message. ${ }^{132}$ In the message, he said that the law would "give the federal government the power to act against those who might move around the

128. Ibid., 3-4.

129. Transcript, Ramsey Clark Oral History Interview V, 3 June 1969, by Harri Baker, Internet copy, LBJ Library.

130. There was considerable contestation between the federal agencies as to the approach of the administration:

HEW feels that juvenile delinquency, social services, rehabilitation, etc. should be heavily emphasized. We feel the President must place a much greater emphasis on crime and law enforcement if he is to strike the right note with Congress and the public. This is not necessarily a programmatic difference, but rather primarily a difference in how the President talks about the problem.

(Memorandum for the Honorable Bill D. Moyers, Special Assistant to the President, from Norbert A. Schlei, Assistant Attorney General, Office of Legal Counsel, LBJ Library. SP 2-3/1965, JL, Law Enforcement \& Administration of Justice 3/8/65)

131. Memorandum to Larry Levinson from Fred Panzer. Subject: Crime Message Booklet, 28 Feb. 1968, LBJ Library, Office Files of Fred Panzer: Crime-1968.

132. Christopher and Clark noted that "Enactment of a Federal act runs the risk of appearing to do more than we can really accomplish." (Memorandum for the President from Joe Califano, 29 Jan. 1968 [10:00 p.m.], LBJ Library, LE/JL). country, inciting and joining in the terror riots."133 Realizing that he could no longer politically afford to decouple crime and civil rights, Johnson also changed his line dramatically in his 1968 State of the Union speech- "The American people ... [h] ave had enough of rising crime and lawlessness" - and the loudest applause from the audience came in parts that attacked crime. ${ }^{134}$ In his message to Congress requesting action on the Safe Streets bill, he had abandoned the poverty approach for more "immediate solutions to the rising crime rate that will help us maintain order." 135

The negotiation and passage of two major bills exemplifies the escalating punitiveness. The first "immediate solution" was the Omnibus District of Columbia Crime bill. Efforts to get a bill passed on crime in the District began in 1958. There had been excessive attention to crime in the District for years; described as a "sick city," it dominated news accounts of crime: "'latchkey' kids who know no family restraint roam the midnight streets, yoking (mugging), beating, and gang-raping." 136 Ramsey Clark and others believed this attention to have motivations above the crime rate, saying that "people always liked to focus on the nation's capital as a crime center" even though "the statistics never supported it" because "it was really a continuation of the old southern belief that the blacks were incapable of self-government." 137

Passed in 1967, it included warrantless arrests for misdemeanors, investigative detention with no charges or Mirandizing (allowing police interrogation of people not charged with a crime), imposed strict mandatory penalties, and prison sentences for inciting to riot. The conservative-dominated District of Columbia crime committees in the House and Senate deleted provisions related to gun control, drug treatment, and rehabilitation, and revised the penal code to include mandatory sentences for certain offenses. This bill attempted to undercut the Supreme Court's Mallory decision by ensuring the admissibility of confessions made in a three-hour investigative detention (the Mallory rule excluded confessions obtained by delaying arraignment). President Johnson vetoed the bill with reservations over detention and the mandatory minimums.

In February 1967, the commission established by Johnson in the 1965 LEAA to study the priorities in criminal justice reform issued its report, The Challenge

133. U.S. House, The Challenge of Crime to Our Society: Message from the President of the United States, $90^{\text {th }}$ Cong., $2^{\text {nd }}$ sess., 1968, Doc. 250, 11 .

134. Lyndon B. Johnson, "Annual Message to the Congress on the State of the Union," 17 Jan. 1968.

135. Lyndon B. Johnson, "Special Message to the Congress on Crime and Law Enforcement," 7 Feb. 1968.

136. Fletcher Knebel, "Washington, DC: Portrait of a Sick City," Look, 4 Jun. 1963, 15.

137. Transcript, Ramsey Clark Oral History Interview V, 3 Jun. 1969, by Harri Baker, Internet copy, LBJ Library. 
of Crime in a Free Society. The commission found "far more crime than ever is reported," and advocated federal aid to local police of "several hundred million dollars annually." Based on this report and its 200 recommendations, Johnson requested from Congress the "most comprehensive set of anti-crime proposals ever sent by a President to Congress," which implemented the recommendations of the report and included a mix of expansive federal gun control legislation, provisions for aid to state innovation in criminal justice, and prisoner rehabilitation. Aides had warned against the move to further "federalize" the crime problem; the Director of Johnson's Crime Commission, James Vorenberg, sent a message to Joe Califano where he strongly admonished restraint: "the 'safe streets' approach runs the risk of the President and the federal government appearing to take very direct responsibility for eliminating or reducing crime on the streets." 138

Although President Johnson's proposed legislation left the House Judiciary Committee with little modification, once on the Floor, the bill was dramatically rewritten by a Republican and Southern Democratic coalition through a series of amendments debated over the course of three days. The Senate did the House one better, foisting even more provisions that were anathema to the president's 22-point program and even attempting to rename the bill. These revisions gave extra funds with the "highest priority" of funds earmarked for riots and civil disorders, reassigned control of funds from the Attorney General to state governors, and expanded the power of electronic surveillance, overriding Johnson's strong belief that wiretapping should only be used in cases related to national security. The two bills were squared in the conference committee, with conservative John McClellan, the Senate sponsor, ultimately triumphing.

The conservatives who controlled crime-related committees influenced nearly every facet of the Safe Streets Act in ways that benefited their aims. One journalist and expert on crime legislation during the 1960 s noted that while the conservative coalition usually "exercises negative control, and merely votes down bills, or parts of bills, that it dislikes," the crime issue provided "an opportunity to exercise positive control, both in the Senate and in the House of Representatives."139 The conservative coalition made sure that the crime legislation would be immune from civil rights challenge and wouldn't get into the hands of those sympathetic to civil rights, teaming

138. Memorandum from Joseph A. Califano, Jr., Special Assistant to the President, from James Vorenberg, Executive Director, President's Commission on Law Enforcement and Administration of Justice, 2 Dec. 1966, LBJ Library, 1966-1967 Task Force on Crime-I.

139. Richard Harris, The Fear of Crime (New York: Frederick A. Praeger, Publishers, 1968), 55. up on several key roll call votes. ${ }^{140}$ First, they amended the law to make sure that disbursement of funds was not based on compliance with the condition of the Civil Rights Act in Title VI, which gave the federal government power to withhold funds from agencies that were racially discriminatory. ${ }^{141}$ They also objected to the grants being administered by the attorney general for fear that he would enforce racial guidelines on local governments. In the Senate hearings on the bill, McClellan grilled Ramsey Clark over his potential authority to require recipient agencies to be racially inclusive. When Clark answered that the Civil Rights Act would indeed apply and that discriminatory law enforcement agencies would be in violation, Senator Thurmond interrupted:

I gave you the illustration that now HEW is trying to get schools to haul children from one place to another specifically to bring up the racial balance in schools. I am asking you here under this bill, coupled with Title VI of the civil rights act, would your director have the right to withhold funds if he wanted a racial balance brought into the personnel of the police department... ? ${ }^{142}$

Title I of the resulting act created a three-person LEAA to administer the grants and stipulated that the LEAA could not require that grant recipients had a racially balanced police force. This dictum was not merely symbolic; some states including Alabama and Mississippi still prohibited blacks from being employed as state police. ${ }^{143}$ Second, they changed the federally administered local grants into state block grants, in one of the most controversial and hotly debated provisions of the bill. The administration's bill had originally designed the grants to go directly to cities and local agencies with populations over 50,000 but House Republicans Everett Dirksen (R-IL) and Gerald Ford (R-MI) proposed to change the structure to block grants to be given directly to states. It was understood that if the money went to cities, agencies controlled by liberal Democrats and blacks in city government would administer it. Alternatively, if the money was channeled through at the state level, governors would have discretion over how the money was used and the majority of governors were ideologically conservative. ${ }^{144}$ Republicans and southern Democrats argued

140. CQ Almanac 1968.

141. CQ Almanac 1967.

142. U.S. Senate, Controlling Crime Through More Effective Law Enforcement, Hearings before the Subcommittee on Criminal Laws and Procedures of the Senate Committee on the Judiciary, $90^{\text {th }}$ Cong., $1^{\text {st }}$ sess., 1967.

143. James Vorenberg, "The War on Crime: The First Five Years," The Atlantic Monthly, May 1972.

144. Indeed the National Conference of Governors lobbied Congress for the block grants. 
vociferously for the block grant amendment, upholding the tradition of attaching local control to federal funding that often resulted in racially discriminatory administration. ${ }^{145}$ Third, the act barred LEAA funds from going to any agency that had ties to the antipoverty agency, the Office of Economic Opportunity (OEO), an agency criticized for being complicit in the riots. ${ }^{146}$ The above are powerful examples of how the conservative coalition used a pet projectcrime-to advance the cornerstones of their prior agenda on civil rights.

Attention to racial disorders figured prominently in the protracted debates around the crime bill:

I do know that our courts and our national leadership has placed too much emphasis on minority rights without regard to the fact that society collectively also has rights.... I am charging the officials at Justice with ignoring their responsibility to society and to the American people in order not to offend certain minority groups. ${ }^{147}$

McClellan and other anti-civil rights legislators had not yet forgiven the Court for disturbing its Jim Crow practices; in a direct example of frontlash, they submitted several provisions to curb the Court. Senator Ted Kennedy implored his colleagues in a close vote on Title II, the provision that would nullify the Court's rulings expanding defendant rights (Miranda, Mallory, and Wade):

For it is these keystones in our tradition of ordered liberty which are threatened here today. They are threatened because other Americans want revenge against a Constitution and a Court which denounced prejudice and discrimination in large segments of American life.... It is ironic that those who rail the loudest about obedience to law as an unshakable absolute, those who inveigh against civil disobedience in all its forms should be in the forefront of an effort to violate the Constitution and rob the Supreme Court of its power ... ${ }^{148}$

While the debates on Safe Streets were going on, the House passed a bill to punish people involved in the riots. The bill was introduced by Representative William Cramer (R-FL), who had originally tried to pass riot penalties as an amendment to the failed 1966 Civil Rights Act. Emmanuel Celler (D-NY)

145. Katznelson, When Affirmative Action was White.

146. Title 1 of the Act "prohibited agencies administered or in any part funded or contracted by the Office of Economic Opportunity from receiving funds under the Act." CQ Almanac 1967, 858. The original amendment was sponsored by Joe D. Waggonner Jr., Democrat from Louisiana.

147. Congressman Rivers quoted in Beth Lynch and Nancy E. Goldberg, The Dollars and Sense of Justice: A Study of the Law Enforcement Assistance as it Relates to the Defense Function of the Criminal Justice System (National Legal and Defender Association, 1973), 7.

148. Qtd. in Harris, Fear of Crime, 86-87. proposed to combine the antiriot legislation with another bill that was to ensure protection of civil rights workers, which had originally been part of the Civil Rights Act of $1966 .{ }^{149}$ Despite it being an uncontroversial provision in 1966, the bill ultimately failed after arch-segregationist William Colmer (D-MS) argued against the combination because he believed the civil rights protection would make the riot punishment futile. Some in Congress objected to the racial connotations of the antiriot bill; William F. Ryan (D-NY) believed the legislation was motivated by the same "white backlash" as that that killed the Civil Rights Act of 1966; Frank Thompson Jr. (DNJ) argued that the bill was for sole purpose of stopping Stokely Carmichael, the black power leader. ${ }^{150}$ Despite the fact that the Commission on Civil Disorders found no evidence of a communist conspiracy, the riots were connected to communism and outside "professional" agitators and antipoverty workers. The DOJ's own video "Riotmakers: The Technology of Social Demolition" explained the riots of the 1960s as being coordinated by professional agitators, which were dubbed "Leninoids." In his statement for the bill, Cramer presented the accounts of officials in cities that had had riots, which alleged the influence and participation of outside agitators; Colmer also claimed the riots were an "organized conspiracy .... backed by the Communists." 151 Many argued that the riots were not disjointed events or spontaneous outbreaks to racial bias and police brutality but were part of a conspiracy. In the hearings on anti-riot provisions, Representative Joel Broyhill (D-VA) argued:

\begin{abstract}
These outbreaks of lawlessness ... are conceived in the twisted minds of the hatemongers, a trained cadre of professional agitators who operate in open defiance of law, order, and decency .... Moving among these people, the dregs of our society, these insidious enemies of our democratic form of government preach a cant of hate and contempt for law and order.... They create fear wherever they go, and feed with delight on this fear.... They train other malcontents in the art of destruction...these vultures of our society carry on their nefarious work on funds provided by the very tax-payers whose lives and property they threaten. ${ }^{152}$
\end{abstract}

The resulting legislation contained a sprawling definition of a riot; for instance, a riot could consist of a public disturbance of a group of only three people, which effectively meant that large peaceful demonstrations with a scuffle between three bystanders

149. This provision was originally included to address the violent resistance to southern integration.

150. CQ Almanac 1967, 783.

151. Ibid.

152. U.S. House, Penalties for Inciting Riots: Report to Accompany H.R. 421, $90^{\text {th }}$ Cong., $1^{\text {st }}$ sess., 1967, Rept. 472, 7. 
could constitute a riot. This legislation also provided for the prosecution of civil rights leaders. ${ }^{153}$ When Congress passed it, many fully expected it to be overturned by the Supreme Court as an unconstitutional abridgement of the First Amendment protections.

After being debated in committee and Congress for two years and suffering the addition of twenty-five amendments to the original administration proposal, the Safe Streets bill was finally sent to the president to sign on 6 June 1968. ${ }^{154}$ Even opponents of the bill, such as John G. Dow (D-NY) felt compelled by public anxiety over crime and riots to vote for the bill:

This bill, as now amended, I regret exceedingly, and will only vote for it because of the widespread desire of all our people to curb crime and prevent continuation of violence in our land. As the price for this, we are saddled with amendments that threaten our liberties and may remain to haunt us. ${ }^{155}$

Members of Congress referred to the blistering public pressure they faced to crack down. Torrents of constituent mail flowed into their offices, and businesses, nonprofits, and civic organizations lobbied for passage of the crime bill. Democrats had witnessed the departure of several colleagues in the midterm elections in 1966-forty-seven representatives and three senators were voted out of office (in addition to eight governors), some for their vote against a crucial crime bill. ${ }^{156}$ A former member of Congress and the House Judiciary Committee wrote the president urging his veto of Safe Streets: "One of the reasons I am no longer in Congress is because I voted against the D.C. [crime] Bill." ${ }^{157}$ Now, fourteen liberal Democrats in the Senate were facing an election a few months away where crime was a major campaign theme.

With only seventeen members of the House voting against Safe Streets and only four in the Senate, no federal agency had come out against it, and, with an impending election four months hence, Johnson's hands were tied, even though the bill was unrecognizable from the administration's proposed legislation and did not include any of the recommendations of the crime commission's 18-month study. Although Warren Christopher called the bill "perplexing" and noted that Congress should have given the president a much better bill, he urged the president to "take into account the very large majorities which supported the bill in Congress," who threatened to

153. Doug McAdam and Kelly Moore, "The Politics of Black Insurgency, 1930-1975," in Violence in America: Volume 2 Protest, Rebellion, Reform, ed. Ted Robert Gurr (Newbury Park, CA: Sage Publications, 1989).

154. For an in-depth recounting of the maneuvering behind Safe Streets, see Harris, Fear of Crime.

155. John G. Dow (D-NY) quoted in Harris, Fear of Crime, 109. 156. Sundquist, Dynamics of the Party System.

157. Letter to the President from George W. Grider, 13 Jun. 1968. LBJ Library, LE/JL 3 6/13/68-6/19/68. override a veto. ${ }^{158}$ Johnson reluctantly signed it five hours before the deadline saying it contained "more good than bad" and with a request that the Congress remove the electronic surveillance provisions. ${ }^{159}$ Most legislators and journalists saw it as a capitulation to public hysteria. ${ }^{160}$ Another aide, Harry McPherson, wrote in a memo to the president that it was "the worst bill you have signed since you took office." "61

The resulting law, 134 pages in length, was the "most extensive federal anti-crime measure in the nation's history." ${ }^{162}$ Safe Streets, which began in a 1965 request from the president for funds for training local law enforcement through categorical grants, gun control, right to privacy (limiting wiretapping), drug control, and agency reorganization, was transformed into a radically different bill before passing in 1968. The 1968 act overturned three major Supreme Court rulings relating to defendants' rights, removed the federal courts' ability to review state court rulings on voluntary confessions, made a huge investment in riot control, and dramatically expanded law enforcement's powers relating to wiretapping. ${ }^{163}$ Much of the gun control legislation requested by Johnson was either not acted on or watered down significantly. In short, this bill had become a "vehicle for 'law enforcement' rather than 'criminal justice' in its journey through the legislature."164 Street crime and riots were folded into same crime package. It was as much about political dissidents and racial conflict in the cities as it was about ordinary crime, perhaps more so. In the first month, \$4 million was disbursed to forty states for riot prevention and control. ${ }^{165}$

Most importantly, under Safe Streets, the federal government would disperse millions of dollars in aid to state law enforcement, the first piece of major legislation to implement block grants and the

158. Letter to Charles J. Zwick, Director, Bureau of the Budget from Warren Christopher, Deputy Attorney General, LBJ Library, Legislation LE/HI-LE/LE 3 [1 of 2].

159. "President Signs Broad Crime Bill, With Objections," in Crime and Justice, 378. Originally printed in The New York Times, 20 Jun. 1968.

160. These sentiments were common in Congress. One anonymous legislator quoted in Business Weekly said: "All anticrime bills have been painted 'antiriot' whether they are or not. When that's the case, you don't dare vote against them this year"” ("GOP Steals a March With Crime," Business Weekly, 19 Aug. 1967, 132).

161. Qtd. in Barry Mahoney, "The Politics of the Safe Streets Act, 1965-1973: A Case Study in evolving Federalism and the National Legislative Process" (Ph.D. diss., Columbia University, 1976).

162. Congress and the Nation, 2:322.

163. Specifically, it allowed any prosecutor with the permission of a judge to tap or bug a suspect of a present or future crime punishable by at least one year in prison. Johnson was so against the wiretapping title of Safe Streets that he sent instructions to every department and agency prohibiting them from using it. His administration was confident that it would ultimately be ruled unconstitutional by the Court.

164. Lynch and Goldberg, "Dollars and Sense of Justice," 6.

165. Feagin and Hahn, Ghetto Revolts. 
revenue sharing concept. It was only the second program of federal assistance to the states designated for crime control (with ancestral ties to the first (OLEA), established three years earlier and expired by the passage of Safe Streets). Compared to the 1965 LEAA's appropriation of $\$ 10$ million, it gave $\$ 400$ million in the first two years for the state planning grants, with a larger budget in following years.

Despite the accuracy problems of the Uniform Crime Reports, a 1968 effort to create a National Crime Statistics Center failed in Congress. ${ }^{166}$ When Representative Larry Winn, Jr. (R-KS) wrote to the president complimenting his crime package but also voicing the concern that it did not contain anything to "upgrade city and state crime reporting,"167 he received a sheepish response from Assistant Attorney General Fred Vinson saying that the Safe Streets Act prohibited the federal government from controlling what the states did with the funds and that it was "in deference to this principle that no positive authorization for crime reporting has been included." ${ }^{168}$ In 1973, the LEAA initiated the National Crime Survey. Based on victimization rates rather than reported crime, it was designed to get more accurate data on crime. The National Crime Survey actually showed higher crime than the FBI reports (as did most other victim-based reports, including the president's crime commission), but it also demonstrated that the crime rate has been relatively stable over time, whereas the FBI reports showed a rapid increase in crime in the 1960s and early 1970s. ${ }^{169}$

If the support for punishment was unrelated to race, then we should expect conservatives to be pushing for stricter punishments for all types of violence and criminal activity. The near universal support for more aggressive criminal justice from the conservative coalition was not extended in one area. They tried to exclude criminal penalties for violations of federally-protected civil rights on account of race (H.R. 2516 and S. 1362 "Interference with Civil Rights Plus Criminal Legislation”). Thus, criminal justice punitiveness cohered more along racial lines;

166. CQ Almanac 1968.

167. The letter from the Congressman said: "Of some concern to me, however, was the absence of a proposal to upgrade city and state crime reporting. It would seem that with the amount of aid granted to law enforcement agencies under the Safe Streets and Crime Control Act of 1967, the Federal government could, at the very least, require certain standards to be met in crime reporting" (Letter from Congressman Larry Winn, Jr. to the President. 7 Feb. 1967, LBJ Library. SP 2-3/1967/JL/Pro/A-Z).

168. Letter from Fred M. Vinson, Jr, Assistant Attorney General, Criminal Division, Dept. of Justice to Honorable Larry Winn, Jr., 21 Feb. 1967, LBJ Library. SP 2-3/1967/JL/Pro/A-Z.

169. In 1965, the Crime Commission ran a survey to get an accurate measure of crime. The results showed that crime was much higher than the UCR reports, or 2,120 crimes per 100,000 compared to 1,434 per 100,000 (Philip H. Ennis, Criminal Victimization in the United States: A Report of a National Survey (Chicago: National Opinion Research Center/University of Chicago, 1967). indeed, as the next section discusses, the racialized crime innovations were also bound up with an attack on civil rights legislation, the poverty programs of the Great Society, and Supreme Court decisions.

\section{The Scapegoat: Civil Rights}

Criminal justice policies were not the only arena affected by the fusion of crime and civil rights; several Civil Rights bills suffered defeat on the justification that they would be seen as rewarding riots and criminality. Consider the memo of one Johnson aide passing on the sentiments of Representative Bill Hungate (D-MO), a member of the Judiciary Committee:

[T] he Civil Rights Bill will not pass in anything like its present form; the feeling on the floor is that we have given enough to Civil Rights workers who have just been stirring up trouble; that the bill could not have come to the floor at a worse time. ${ }^{170}$

Indeed, after 1965, Congress' civil rights agenda slowed considerably. More of the Kerner Report's recommendations on law enforcement were implemented than its vast program for reducing deprivation in the cities. Crime became an excuse for not expanding civil rights and social justice. Civil rights and crime were inversely related on agenda; as action on civil rights withered, criminal justice was expanded.

The focus on violence had predictable effects, spilling over into discussions of civil rights. As racial disorders spread throughout cities across the country, civil rights related agencies and court decisions came under attack for being complicit in the disorder, in the strong version, and for indirectly aiding racial disorder by giving in to the early demands of "agitators," in the more discreet account. In the 1967 debates over extending the Office of Economic Opportunity, one of the primary arguments against it was that poverty programs were connected to black insurgency and lawlessness. Representative Paul Fino (R-NY) maintained:
There is little doubt that the Office of Econ- omic Opportunity has been at the bottom of much of the rioting and troublemaking which we have sadly witnessed in the past few years throughout this country.... It has hired muggers and criminals. It has subsidized revo- lution and social agitation. ${ }^{171}$

In the 1967 congressional debates over passing the anti-riot act, law enforcement officers from various cities testified that antipoverty workers had participated in the riots; indeed, one accused the OEO of giving a grant of $\$ 7,700$ to a leader of the riots in

170. "Memorandum for Barefoot Sanders from Sherwin Markman," 14 Aug. 1967, LBJ Library. LE/HU2 4/12/67-3/11/68.

171. Qtd. in Carol A. Horton, Race and the Making of American Liberalism (Oxford: Oxford University Press, 2005), 183. 
Nashville. ${ }^{172}$ Some, such as Representative William Chappell (D-FL), identified the earlier "permissiveness" of the Supreme Court as a key cause behind the riots: "But when the courts ruled that certain disruptive marches were in order because of their own sense of social reform, the destruction and riots that followed must be laid at the judicial doorstep."173

In the final section of this article, I show how the conservative policy monopoly expanded and the new paradigm was further enshrined in crime legislation.

\section{Continuing to Get Tough and "Combat Lawlessness": The Nixon Years}

After the assassination of Martin Luther King, Jr., in April 1968, 142 cities across the U.S. erupted in racial confrontations, resulting in 43 deaths and 27,000 arrests. ${ }^{174}$ The District of Columbia witnessed arguably the most severe violence: property damage included 1,200 buildings and homes torched, while the human toll included 12 dead, 1,200 injured, and 7,600 arrested. ${ }^{175}$ Hoover's monthly crime clocks in the Uniform Crime Reports depicted an epidemic (Figure 8).

Presidential candidate Richard Nixon launched a frontal assault on Johnson's approach by saying the crime rate would decrease more by doubling convictions than quadrupling the war on poverty and that now was the time to start doing something concrete rather than studying crime with more commissions. Nixon released a position paper titled Toward Freedom from Fear, countering the root causes paradigm: "We cannot explain away crime in this country by charging it off to poverty." ${ }^{176}$ Law and order was the centerpiece of the Nixon campaign, having learned much from Ronald Reagan's successful deployment of the law and order theme in the 1966 California gubernatorial election. In the course of the 1968 presidential campaign, Nixon dedicated seventeen speeches solely to the topic of law and order. One televised campaign advertisement began with frightening music accompanied by quickly flashing pictures of protesters, violence, bloodied victims, and mayhem. An authoritative voice followed, saying:

It is time for an honest look at the problem of order in the United States. Dissent is a necessary ingredient of change, but in a system of government that provides for peaceful change, there is no cause that justifies resort to

172. CQ Almanac 1967, 784

173. William V. Chappell, "Crime: Some Call it Dissent" [address 30 Mar. 1970], Vital Speeches of the Day 36 (1970): 424.

174. U.S. Senate, Permanent Subcommittee on Investigations of the Committee on Government Operations, Staff Study of Major Riots and Civil Disorders.

175. Ted Robert Gurr, "Protest and Rebellion in the 1960s: The United States in World Perspective," in Violence in America: Volume 2 Protest, Rebellion, Reform.

176. Nixon, "Toward Freedom from Fear," 12936. violence. Let us recognize that the first right of every American is to be free from domestic violence. So I pledge to you, we shall have order in the United States.

At the end a caption read: "This time ... vote like your whole world depended on it . . NIXON."177 While sanitized from the outright racism of the Goldwater and Wallace campaigns, Nixon's strategy was based on the linkages between racial conflict and lawlessness; indeed, in viewing his own campaign ad, he remarked triumphantly that it "hits it right on the nose. It's all about law and order and the damn Negro-Puerto Rican groups out there'."178

Hubert Humphrey's campaign tried to respond, toughening their approach. Humphrey accepted the Democratic party's nomination in 1968 by saying "rioting, burning, sniping, mugging, traffic in narcotics, and disregard for law are the advance guard of anarchy, and they must and they will be stopped."179

With the mandate of the "law and order" election behind him, the Nixon administration submitted twenty pieces of anti-crime legislation (including pretrial detention) and issued a memo declaring the DOJ's right to use electronic surveillance on any subversive group without getting permission from the courts. Nixon continued the tradition of his predecessor to make speeches and messages on crime. However, unlike Johnson, who rarely deplored lawlessness without also mentioning the squalor of poverty in the cities, Nixon blamed crime on permissiveness-of society, of parents, and of the courts. Fear was prominent in his speeches:

\section{If we allow it to happen, then the city jungle will cease to be a metaphor. It will become a barba- ric reality, and the brutal society that now flourishes in the core cities of America will annex the affluent suburbs. ${ }^{180}$}

In 1969, the National Commission on the Causes and Prevention of Violence (commonly known as the Eisenhower commission) issued their final report To Establish Justice, To Insure Domestic Tranquility. Containing a mixture of solutions, it painted a picture of what the future city would be like if the problem of violent crime continued:

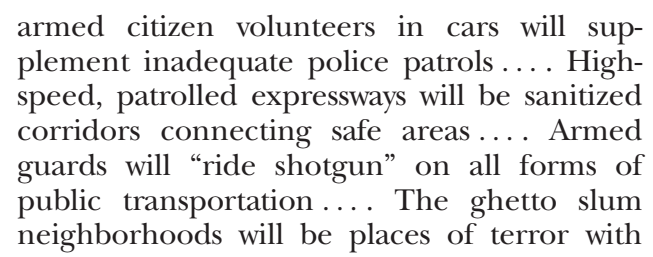

177. American Museum of the Moving Image.

178. Quoted in Philip A. Klinkner and Rogers M. Smith, The Unsteady March: The Rise and Decline of Racial Equality in America (Chicago: University of Chicago Press, 1999), 292.

179. CQ Almanac 1968, 1042.

180. Nixon, "Toward Freedom from Fear," 12936. 

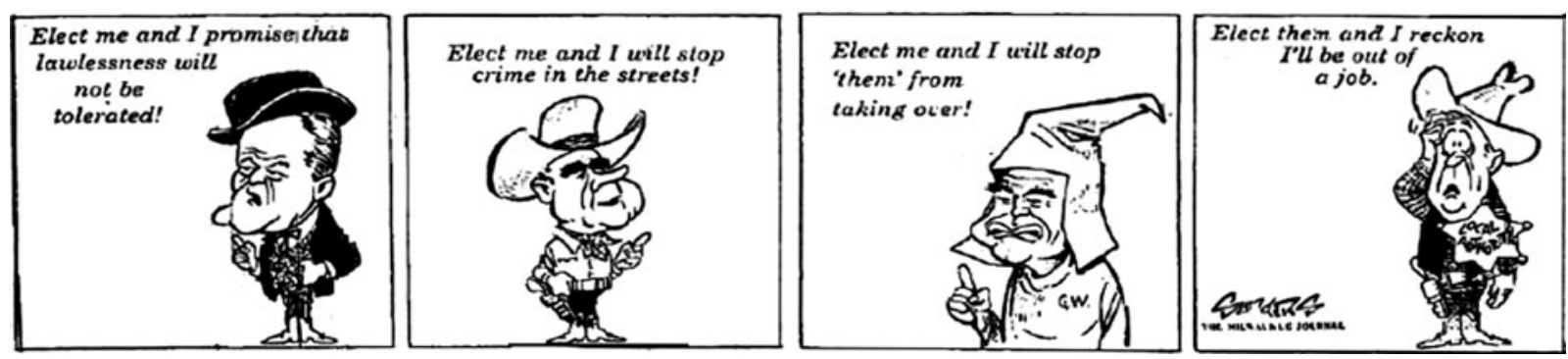

Fig. 8. Time magazine cartoon from October 4, 1968.

Note: Reprinted with permission from the original publisher, the Milwaukee Journal-Sentinel.

widespread crime, perhaps entirely out of police control during night-time hours. ${ }^{181}$

If Johnson took the federal government's role in crime control from zero to a hundred in scale, Nixon took it from one side of spectrum to the other in approach. Crime control during the Nixon administration continued the tradition of expanding federal involvement with more state power over the administration of funds, and both of these along with a more tough orientation to crime, law enforcement, and criminal justice. Based on Nixon's request, Congress quadrupled appropriations for the LEAA, going from \$59 million in 1969 to $\$ 268$ million in $1970 .^{182}$ Nixon declared drug abuse the most important problem in the United States in 1969 and announced a "War on Heroin," sending several narcotics bills to Congress concentrated on punishment (rejecting the Commission's report recommending decriminalization). Meanwhile, the Controlled Dangerous Substances Act of 1969 set off a contentious debate over jurisdiction between HEW and DOJ officials over whether drug addiction should be an issue for law enforcement or health. In 1970, Nixon formed the Office of Drug Abuse Law Enforcement (ODALE), creating the crime strike forces that greatly increased policing and surveillance in black communities.

The National Commission on the Causes and Prevention of Violence recommended "a national commitment to double our investment in the administration of justice ... a modest price to pay to 'establish justice' and 'insure domestic tranquility' in this complex and volatile age." ${ }^{183}$ Ultimately the LEAA would be amended six times and was expanded financially and given more authority over criminal justice at lower levels of government. The initial expenditure for the LEAA went from $\$ 10$ million in 1965 to $\$ 850$ million in $1973 .^{184}$

181. National Commission on the Causes and Prevention of Violence, To Establish Justice, 44.

182. CQ Almanac 1969, 687.

183. National Commission on the Causes and Prevention of Violence, To Establish Justice, 157.

184. Lynch and Goldberg, Dollars and Sense of Justice.
By 1970, the riots had subsided but the war on crime campaign was in full swing and showed no sign of abating. During his campaign, Nixon had focused on crime in the District of Columbia, calling it the "crime capitol of the nation" and a "national laboratory" for his proposals. Despite the fact that it ranked twenty-seventh (of fifty-two large cities) on crime, trailing far behind Denver, Chicago, New York, and others, Nixon submitted an anti-crime bill to Congress specifically concerned with Washington, D.C. The District of Columbia crime bill of 1970 was the "most innovative" and expansive of Nixon's proposed legislation. It was so broad that it was opposed vigorously by conservative Representative Sam Ervin-who had usually led the campaign for punitive crime policies in the Senate-because he thought it unconstitutional: "the Nixon Administration's major contribution to the D.C. Crime Bill was a grab bag of some of the most bizarre and repressive crime-control measures ever proposed to the Congress," warning that "we must be extremely skeptical of the other administration 'law and order' proposals which are also advertised as 'indispensable' for crime control." 185 The bill mandated five-year sentences for anyone convicted of a second armed offense and allowed life sentences for offenders convicted of a third a felony, extended broad wiretapping authority, established "no knock" policies for police (going directly against the Court's search and seizure rulings), reorganized District Courts (which ultimately doubled felony indictments), allowed juveniles to be tried as adults (resulting in 60 percent of youths going to adult courts), eliminated juvenile jury trials, and allowed "preventive detention" (ultimately, overturning the Bail Reform Act of 1966 to allow people to be held without bail). ${ }^{186}$ The preventive detention proposal

185. Sam J. Ervin, Jr., "Failure of Preventive Detention," in Crime and Justice, 394. Originally printed in The New York Times, 19 Aug. 1972.

186. The "no knock" provision meant that police could legally enter a residence without knocking first if lives would be endangered or if the evidence would be compromised. 
was the most controversial, allowing some "dangerous" suspects to be detained for sixty days before conviction. Despite a campaign against it in the Senate by civil libertarians, it passed on the eve of the election. More than just a bill for the District, this legislation "also represented the national crime policy of the Nixon Administration." 187

The Eisenhower Commission had originally provided a dual emphasis on unemployment and ghetto conditions. Its report argued that "Warring on poverty, inadequate housing and unemployment, is warring on crime. A civil rights law is a law against crime." ${ }^{188}$ However, this dual focus was not reflected in policy. While law enforcement was expanding, poverty programs were reduced or eliminated altogether. Law enforcement was the only program that escaped cuts, and actually expanded, in Nixon's budget proposals. There was almost no new civil rights legislation. Impact Cities, a law enforcement program, replaced Model Cities.

When Nixon entered the White House, the crime problem that he had helped to fan, awaited his administration; now he would be in the position of having to make the crime rates go down, or in the words of one journalist, "he was being asked to sit down on the chair that he had scattered tacks on." 189 Crime had actually gotten worse since Republicans took over, increasing 25 percent from 1968 to 1970. Under the Omnibus Crime Control and Safe Streets Act of 1968, the Attorney General was "to collect, evaluate, publish and disseminate statistics." 190 Using this authority, Nixon's Attorney General, John Mitchell, personally submitted the statistics, putting a different spin on crime increases that would have made the "law and order" policies look bad. J. Edgar Hoover's report on crime statistics was rewritten by Mitchell's public relations staff to show that crime had improved during the Nixon administration in comparison to the Democratic administrations that preceded it. One tactic used to make it seem like crime was decreasing and was much worse during the Johnson years was accomplished by using rate of increase instead of the crime rate. Thus, for instance, in the first three months of 1970, the Uniform Crime Reports showed an increase in crime by 13 percent compared to the first three months of 1969. Mitchell's office revised this statement to say "the rate of increase of violent crimes in the first three months of 1970 slowed by 7 percent in the major cities of the nation-and by 3 percent in the nation

187. Warren Weaver, Jr., "Senate Approves Stiff Crime Bill For Washington," in Crime and Justice, 382. Originally printed in The New York Times, 24 Jul. 1970.

188. National Commission on the Causes and Prevention of Violence, To Establish Justice, 55.

189. Harris, Justice, 105

190. CQ Almanac 1968. as a whole."191 If the Nixon administration could show that its harsh policies were working lower, it could use this in the 1972 election: "By 1971, several aides in both the White House and the Office of Management and Budget $(\mathrm{OMB})$ were regularly prodding LEAA to move faster to provide concrete evidence of a federal impact on crime rates." ${ }^{\text {"192 }}$ In addition, Nixon pointed to the District crime bill as the reason behind crime drops in the nation's capital during his tenure. The "audit," conducted by a major contributor to his campaign (Ernst and Ernst) found a decrease in crime of 50 percent. ${ }^{193}$ However, an analysis by the Brookings Institution found that the decrease was due to a change in the value of stolen goods, decreasing the number of crimes classified as burglary or larceny. ${ }^{194}$

Former Attorney General Ramsey Clark warned against the drive for more punitiveness:
Those who stimulate prejudices in public opinion, who appeal to base instincts of fear, who protest their willingness-even desire- to sacrifice freedom on the altar of order add immeasurably to the burdens of achieving excellence in the performance of criminal justice agencies. $^{195}$

Those agreeing with Clark were now in the minority; even liberal Democrats did not talk about civil rights without deploring crime. In the 1969 mayoral and 1970 midterm elections, there was a clear attempt to reposition themselves on the crime issue. The law and order stance had been vindicated in the two preceding elections and crime was still the number one issue among voters, competing only with race relations (arguably, part of the same class of issues). Seeking to suspend the charge of being soft on crime and coddling criminals, many posed in campaign photos with police, and threw their support toward anti-crime legislation formulated by the Nixon administration. ${ }^{196}$ New York City Mayor John Lindsay, having been defeated in the Republican primary, continued the campaign as a Liberal party candidate, stressing that he had increased the police force by 5,000 and promised more if reelected. Relatively unknown candidates with law and order

191. Qtd. in Fred P. Graham, "Mitchell and Hoover: Focus Differs on Crime Data," in Crime and Justice, 269; emphasis added. Originally printed in The New York Times, 8 Sept. 1971.

192. Cronin, Cronin, and Milakovich, U.S. v. Crime in the Streets, 95.

193. Hannah Shields and Mae Churchill, "The Fraudulent War on Crime," The Nation, 21 Dec. 1974, 648-55.

194. Robert B. Semple, Jr., "Nixon Says He Kept Vow To Check Rise in Crime," in Crime and Justice, 271. Originally printed in The New York Times, 16 Oct. 1968.

195. Ramsey Clark, "Liberty and Safety," in Crime and Justice, 384. Originally printed in The New York Times, 19 Nov. 1968.

196. John Herbers, "Democrats Shift to Right, in Line with G.O.P., on Crime Issue," in Crime and Justice, 268-69. Originally printed in The New York Times, 12 Oct. 1968. 
platforms upset elections in several mayoral elections from New York to Minneapolis.

Shortly after the D.C. crime bill, the usual law and order suspects-McClellan, Hruska, and Ervinsponsored yet another bill. The Organized Crime Control bill, despite its title, actually increased penalties for a wide variety of offenses, most of which were not related to organized crime syndicates at all. It changed criminal procedure, establishing mandatory sentence enhancements for habitual offenders. The template for the habitual offender legislation in the 1970 s, it allowed judges to enhance the sentence of a convicted criminal by a mandatory thirty years if the offender had two prior convictions or a first-time offender who had committed a crime deemed by the judge to be "a pattern of criminal conduct" or if the criminal was deemed to be a "dangerous special offender." Senators Philip Hart and Ted Kennedy proposed that it be amended to apply only to organized crime offenses but the amendment failed. The resulting bill passed in the Senate by a vote of 73 to 1 .

The policies passed in these few years did not simply augment state crime control efforts or extend a path already traveled in previous eras. This infusion of federal assistance to state systems of crime control was the first of its kind and the change it wrought cannot be overstated. The LEAA, once a small pilot program initiated by Johnson and his desire to root out the causes of crime and debated in Congress on one single day without opposition, had become a mammoth institution to "combat lawlessness" and resulted in the funding and creation of 80,000 state and local projects. Ironically, the same "states rights diehards" that the Johnson administration worried about offending in passing the LEAA in 1965, came to be the main activists in the war on crime. For the first time, the federal government launched a full scale program of aid to the states with appropriations totaling $\$ 7.25$ billion, which today translates into approximately $\$ 28$ billion dollars, however, the cost was probably much greater because of the matching funds required by states. Most of the grant money went to suburbs and rural areas rather than cities, and riot control funds went to hardware (including an armored tank in Birmingham), weapons, teargas, and training (i.e. "riot squads"), rather than police-community relations. LEAA's first report showed the breakdown of how federal funds were distributed: 3.5 percent to crime research; less than 5 percent to police relations with the community; 5.5 percent to improving courts; 8.5 percent to rehabilitation; 22 percent to riot control; and the most, 30 percent, to the police. ${ }^{197}$ The LEAA was given a budget twice the size of the FBI and half of the total DOJ budget; it became the "fastest-growing agency in the federal government"

197. Harris, Justice, 178. in the 1970s. ${ }^{198}$ Once in place, this legislation and the agencies it spawned were extremely durable and the DOJ's role in crime control would remain to the present, but that is another chapter of the historical development of criminal justice.

\section{Alternatives}

If reducing crime was primary goal of legislators, policy instruments were available, including the one that had been favored for the existence of the republic-that crime was a problem for local government and federal involvement would constitute a breach of the democratic impulse against a national police state. Actors had to choose to break with past approaches. The characteristics of policies themselves are inconsistent with the interpretation that a break was an inevitable response to crime passing some unacceptable threshold. The policies initiated and ultimately enacted were not logically connected to the goal of crime control; crime was rising fastest in rural areas, the category of crime increasing most was propertybased offenses, and the reasons for the increase ranged from demographic changes from the baby boomers to migration. Several components of the legislation discussed here suggest additional motivations and aims.

The coalition behind the legislation strategically twisted legislation in directions that had more to do with racial ideology. Many obvious examples include exempting Safe Streets from provisions of the Civil Rights Act and barring federal crime program funds from going to the OEO. The crime legislation was purposefully designed so that federal funds would be controlled by state governments, who could in turn distribute funds to localities without any fear of civil rights challenges. Positions on the crime policies cohered more along lines of racial ideology; indeed, debates over crime legislation featured significant attention to race and carried significant implications for racial equality (such as block grants to state governments rather than directly to cities with significant populations of blacks). Votes on key provisions bore striking similarity to the vote breakdowns on civil rights legislation. Votes cast in opposition to open housing, busing, the Civil Rights Act and other measures time and again showed the same divisions as votes for amendments to crime bills. Moreover, those members of Congress who voted against civil rights measures proactively designed crime legislation and aggressively fought for their proposals. And this stance was itself inconsistent with motivation that was purely a conservative ideological stance against crime. For example, the same actors who tried to pass criminal penalties for freedom

198. Christian Parenti, Lockdown America: Police and Prisons in the Age of Crisis (New York: Verso, 1999), 14. 
rides and sit-ins were the major initiators of punitive crime legislation; but they also bitterly opposed a bill for penalties for violence against civil rights workers. Moreover, they pursued policies at odds with what their ideology of limited federal government would dictate. The same group that opposed civil rights legislation on the grounds that it should be left to state control were at the helm of passing federal criminal justice legislation that would extend the federal government's authority. Thus, when the goals of the group defeated on civil rights pointed to a stance of more federal power, they abandoned the states-rights argument. Further, crime did not matter to conservatives until it was clear that it could be used as new currency to reestablish political advantage. Even in the 1960 election with Nixon, a time when crime had been rising substantially, crime is not a subject in campaign speeches. Together, these examples highlight a basic conclusion: it wasn't in their interest to push crime except for race.

Until racial disorder was defined as a crime problem, there was no mobilization on the crime issue and very little policy change. In fact, on at least three prior occasions proposals for federal assistance to local law enforcement had been evaluated, first in the Wickersham Commission's report during the Hoover administration, then a federal aid program was considered 1955 at President Eisenhower's request (to give local governments federal aid to help them deal with juvenile crime), and again in 1961 by the Civil Rights Commission's report to Congress. In all these cases, despite strong endorsement from the administration, opposition to a nationalized police force and a longstanding tradition of local jurisdiction was a check on expansion and the recommendations were rejected. Policy change was a likely outcome when a set of factors converged and were catalyzed by elite goals. The coalition of conservatives who now had a stake in the crime problem, now supported a federal intervention and ensured that it "converged with, and sustained, intense southern provisions." 199

Current explanations obscure these political interests, made even more urgent by the loss on several significant pieces of civil rights legislation. So for different reasons, then, each of the frameworks (opposed as they are about the role of crime) miss the political dynamics that led to the transformation of policies and each isolates crime from the racial context and distribution of power in which it came to matter politically. Avoiding a myopic focus on crime rates allows a view of the entire body of considerations that went into the design of criminal justice policies. The theory of frontlash argues that crime was used in the service of reacting to racial dislocations, a strategy that was vindicated by the rising

199. Katznelson, When Affirmative Action was White, 61. crime rate. Without consideration of elites' strategic preferences, these alternative frameworks cannot explain the sudden mobilization of the crime issue, its momentum, and its connection to the rights revolution. They come up short in explaining why policy disputes over criminal justice formed along racial cleavages or why crime became entangled with racial unrest.

Other alternatives deserve mention; the collapse of the rehabilitation approach and the appetite for punishment among the public have become adages used to explain the punitive doctrine in the U.S. both historically and in comparative perspective. Casual observers to experts of criminology frequently attribute the punitive turn in the United States to the collapse of the "rehabilitative ideal" as an approach to crime. According to this account, two highly visible publications are credited with the reversal of course in criminal justice: Robert Martinson's 1974 essay "What Works?" in the Public Interest and James Q. Wilson's bestselling 1975 book, Thinking about Crime. The former argued that there was no evidence that rehabilitation worked in reducing recidivism, while Wilson's book extended this theme the following year, arguing that the approach to crime should be crime-specific and concerned with manipulating the costs of offending. While these manifestos were extremely influential pieces, they were more likely consequences than causes of the punitive policy changes. Published long after Safe Streets, the District of Columbia crime bill, the Organized Crime Control Act, and key critical policy changes, they were part and parcel of the punitive momentum beginning a decade prior to their publication. This is not to say the arguments they advanced were insignificant; much to the contrary, they likely contributed additional ammunition for the punitive problem framing and helped maintain a course that had already been in motion for several years. But the rehabilitative approach to crime did not "collapse" of its own volition.

Another alternative explanation that is also deeply entrenched in thinking about crime and the "get tough" movement is that the public drove the criminal justice crackdown while legislator's merely responded to public hostility to crime. A full examination of public opinion on crime and criminal justice would demand another analysis and is fraught with problems of inconsistent survey measures during the period of interest. However, a simple exploration of the timing of public opinion shifts on crime provides a crude test of this alternative. Figure 7 depicts the proportion of the public choosing crime as the most important problem in the nation over time; the salience of crime remains low until 1966 , after the issue was a key theme in the ' 64 election and indeed after the first legislative proposals were enacted into law. Similarly, a composite measure of public opinion over time shows public 
- - Crime Concern $\longrightarrow$ Punitiveness

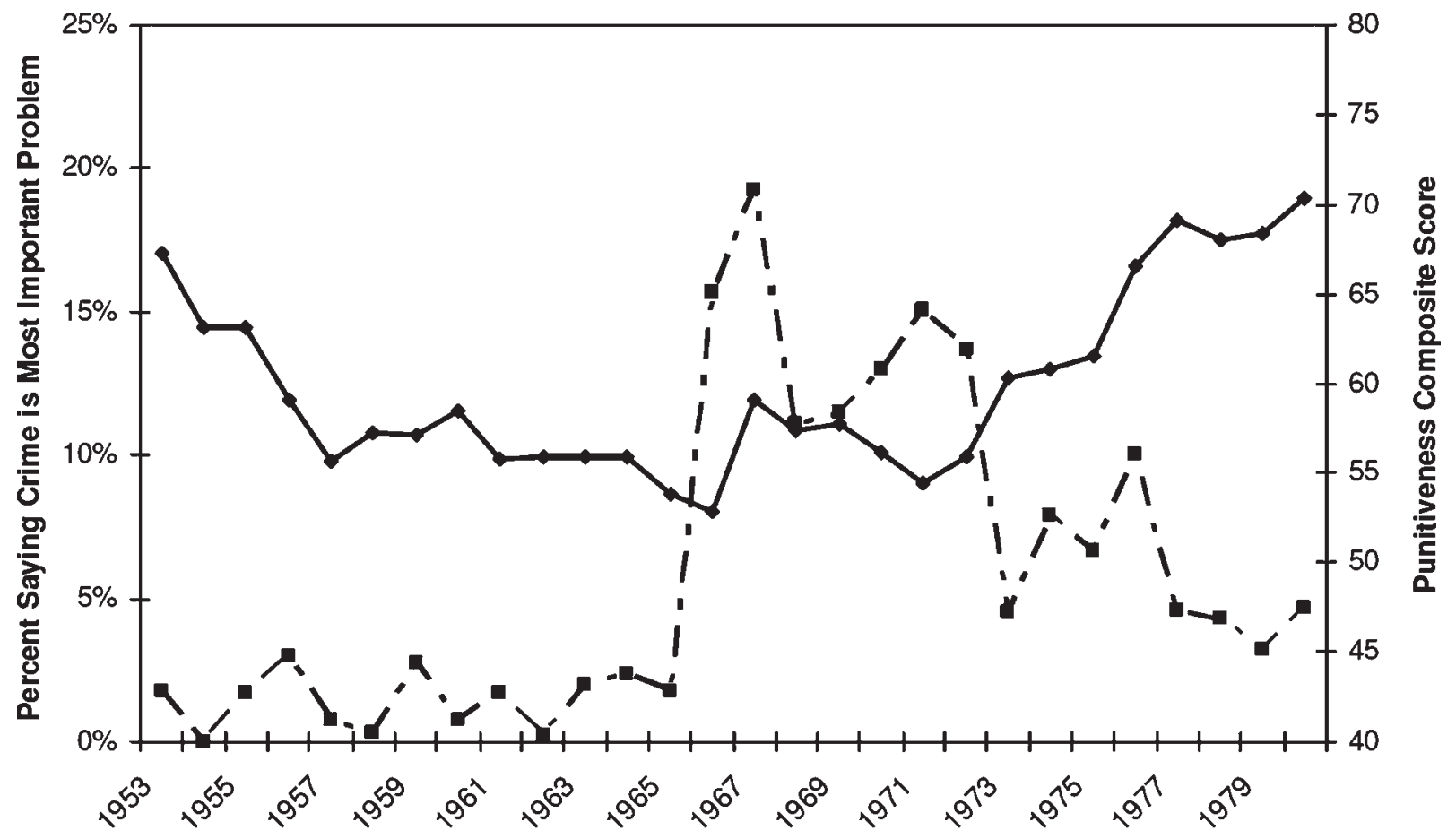

Fig. 9. Crime Salience and Punitive Attitudes Over Time.

Sources: Crime Concern (as measured by the Most Important Problem) is based on Baumgartner and Jones's Policy Agendas Project data. Composite measure is based on original indicator generated by author using WCALC.

preferences on criminal justice were actually decreasing in punitiveness until turning upward in 1967 (see Figure 9). ${ }^{200}$ Several other scholars echo the finding that public concern with crime is the tail to the kite of elite initiative. Beckett's study finds that public concern with crime is correlated with elite attention and appeals around crime, but

200. I compiled all polls related to criminal justice that were asked at least two times between 1950 and 1990 and calculated a composite measure of 'policy mood' using James Stimson's algorithm. This technique enables analysis of global public opinion using survey marginals on related and overlapping survey items. For more information, see Paul M. Kellstedt, "Media Framing and the Dynamics of Racial Policy Preferences," American Journal of Political Science 44 (2000): 239-55; Paul M. Kellstedt, The Mass Media and the Dynamics of American Racial Attitudes (Cambridge, UK: Cambridge University Press, 2003). The program can be found at www. unc.edu/ jstimson last accessed: 13 Dec. 2005. To gather items on criminal justice, I searched Gallup, the Odum Institute holdings, several national surveys including the ANES and GSS, as well as Roper Center holdings. The resulting criminal justice composite measure includes 11 series containing questions on the death penalty, rights of the accused, harsh courts, and spending on various aspects of criminal justice. By treating these separate indicators as part of a global disposition, I sidestep the problem of inconsistent survey measures that has prevented scholars studying public opinion on race and crime from longitudinal analysis. not with crime. ${ }^{201}$ The public did not register high levels of crime concern until after Goldwater's campaign appeals and particularly his nomination speech. ${ }^{202}$

Two scholars located the original output from surveys with crime measures during the 1960s and found that a disturbing number of surveys were blatantly misreported or conflated categories of lawlessness and crime. Moreover, they show how the media selectively reported public polls on crime and surveys were used to manipulate the image that public opinion was favorable. Survey categories represented elite discourse rather than public perception and lumping together categories was an "elite-sponsored social construction." The concepts of crime and race (civil rights) became related after elite initiative, with the public registering changes after elite discourse. Crime was not the uppermost concern to the public, who until fairly late distinguished race, civil rights, and insurgency from crime; "The press and the public were

201. Beckett, Making Crime Pay.

202. Dennis D. Loo and Ruth-Ellen M. Grimes, "Polls, Politics, and Crime: The "Law and Order" Issue of the 1960s," Western Criminology Review 5 (2004): 50-67. 
accustomed to viewing crime in terms of judicial leniency, civilian complaint review boards, interrogation, and capital punishment. They did not understand how crime in the streets and the 1964 summer disorders in Harlem and Philadelphia related to the criminal justice system's lack of financial resources." 203

\section{Conclusion}

In this article, I have demonstrated the centrality of racial struggle in the political development of criminal justice at the national level. Relying on a rich documentary history, I have shown how the reaction to the success of the civil rights movement became embedded in a separate policy process. Resistance to civil rights was reconstituted in a new policy domain by turning objective conditions into political capital. Changes in the racial status quo, and not simply rising crime, were an important and overlooked factor, and in its strongest versionpunitive criminal justice was part of the price of civil rights liberalizations. The transformation of criminal justice was not merely an exercise in crime fighting; it both responded to and moved the agenda on civil rights. Rather than a temporal coincidence, the graveyard of civil rights legislation was the same place where crime bills were born.

203. Caplan, "Reflections on the Nationalization of Crime," 612.
Much of the legislative activity on crime came out of the same hand that fed the early opposition to civil rights, leaving their mark on public policies long after the riots and demonstrations ended. Through a frontlash, rivals of civil rights progress defined racial discord as criminal and argued that crime legislation would be a panacea to racial unrest. This strategy both imbued crime with race and depoliticized racial struggle, a formula which foreclosed earlier "root causes" alternatives. Viewed in this way, the truism that a crime wave was the cause of legislative activism on penal reform becomes problematic. Punitive crime policies were borne of racial struggle; violence was only one part of a larger, more complex set of factors placing crime on the agenda and ultimately, leading to the passage of policies that would change the nature of punishment. The emergence of crime on the agenda was as durable as it was sudden, molding the path it traveled in the next few decades. The contestation over this issue was not a flash fire that quickly burned out; rather, the paths that were blazed in this moment had a continuing impact on crime policy to the present, though the racialized connection would shift from being a causal argument and implicit rhetorical device to being a tangible outcome once the effects of these policies manifested themselves. 